\title{
Conformation and Dynamics of Human
}

\section{Urotensin II and Urotensin Related Peptide in}

\section{Aqueous Solution}

Elke Haensele, ${ }^{a}$ Nawel Mele, ${ }^{b}$ Marija Miljak, ${ }^{b}$ Christopher M. Read, ${ }^{c}$ David C. Whitley, ${ }^{a}$ Lee Banting, ${ }^{a}$ Carla Delépée, ${ }^{d}$ Jana Sopkova-de Oliveira Santos, ${ }^{d}$ Alban Lepailleur, ${ }^{d}$ Ronan Bureau, ${ }^{d}$ Jonathan W. Essex, ${ }^{b}$ and Timothy Clark. ${ }^{e, *}$

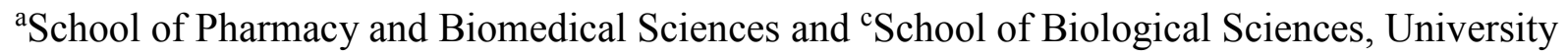
of Portsmouth, Portsmouth PO1 2DT, United Kingdom

${ }^{\mathrm{b}}$ School of Chemistry, University of Southampton, Highfield, Southampton SO17 1BJ, United Kingdom

${ }^{\mathrm{d}}$ Normandie Université, CS 14032 Caen Cedex 5, France, Centre d'Etudes et de Recherche sur le Médicament de Normandie (CERMN, EA 4258, FR CNRS 3038 INC3M SF 4206 ICORE), UFR des Sciences Pharmaceutiques, Université de Caen Basse-Normandie (UNICAEN), F-14032 Caen, France

${ }^{\mathrm{e} C o m p u t e r-C h e m i e-C e n t r u m ~ a n d ~ I n t e r d i s c i p l i n a r y ~ C e n t e r ~ f o r ~ M o l e c u l a r ~ M a t e r i a l s, ~ F r i e d r i c h-~}$ Alexander-Universität Erlangen-Nürnberg, Nägelsbachstraße 25, 91052 Erlangen, Germany

*E-Mail: tim.clark@fau.de 
Abstract. Conformation and dynamics of the vasoconstrictive peptides human urotensin II (UII) and urotensin related peptide (URP) have been investigated by both unrestrained and enhanced-sampling molecular-dynamics (MD) simulations and NMR spectroscopy. These peptides are natural ligands of the G-protein coupled urotensin II receptor (UTR) and have been linked to mammalian pathophysiology. UII and URP cannot be characterized by a single structure but exist as an equilibrium of two main classes of ring conformations, open and folded, with rapidly interchanging subtypes. The open states are characterized by turns of various types centered at $\mathrm{K}^{8} \mathrm{Y}^{9}$ or $\mathrm{F}^{6} \mathrm{~W}^{7}$ predominantly with no or only sparsely populated transannular hydrogen bonds. The folded conformations show multiple turns stabilized by highly populated transannular hydrogen bonds comprising centers $\mathrm{F}^{6} \mathrm{~W}^{7} \mathrm{~K}^{8}$ or $\mathrm{W}^{7} \mathrm{~K}^{8} \mathrm{Y}^{9}$. Some of these conformations have not been characterized previously. The equilibrium populations that are experimentally difficult to access were estimated by replica-exchange MD simulations and validated by comparison of experimental NMR data with chemical shifts calculated with density-functional theory. UII exhibits approximately $72 \%$ open : $28 \%$ folded conformations in aqueous solution. URP shows very similar ring conformations as UII but differs in an open:folded equilibrium shifted further toward open conformations (86:14) possibly arising from the absence of folded N-terminal tail - ring interaction. The results suggest that the different biological effects of UII and URP are not caused by differences in ring conformations but rather by different interactions with UTR. 


\section{Introduction}

The neuropeptide urotensin II (UII) was originally found in the urophysis of teleost fishes. ${ }^{1}$ A human homologue ${ }^{2}$ of the orphan receptor GPR14 3 (a G-protein coupled receptor (GPCR) that is very similar to the somatostatin receptor first isolated from rats) was identified in $1999 .{ }^{4-}$ ${ }^{6} \mathrm{UII}$ is the natural ligand of this receptor, now called the urotensin II receptor (UTS2R, UTR). All vertebrate isoforms of UII show a highly conserved C-terminal sequence: a cyclic 6-residue moiety (CFWKYC) closed by a disulfide bridge and flanked by valine as extra-annular residue (Scheme 1). ${ }^{7}$ The length of the N-terminus of human UII is four residues but this is species variable, so that the total peptide length ranges from 11 residues for human UII up to 17 for hamster UII. ${ }^{7-10}$ Urotensin related peptide (URP) is a paralog of UII. ${ }^{11}$ It has the same Cterminal cyclic moiety as UII but the extra-annular N-terminus of UII is replaced by a single alanine at position 1 in URP (Scheme 1). ${ }^{12}$ The 6-membered ring closed by a disulfide bridge is a common motif with other hormone peptides, such as $\mathrm{Arg}^{8}$-vasopressin and $\mathrm{Leu}^{8}$-oxytocin. UII is the most potent vasoconstrictive natural peptide known ${ }^{2}$ and both UII and URP are thought to be involved in important physiological processes such as cardiovascular regulation, endocrine and behavioral effects. ${ }^{7,8,11,13}$ Consequently, they are linked to a multitude of pathophysiological processes such as atherosclerosis, heart failure, and many more. ${ }^{7,8,11,13,14}$

a

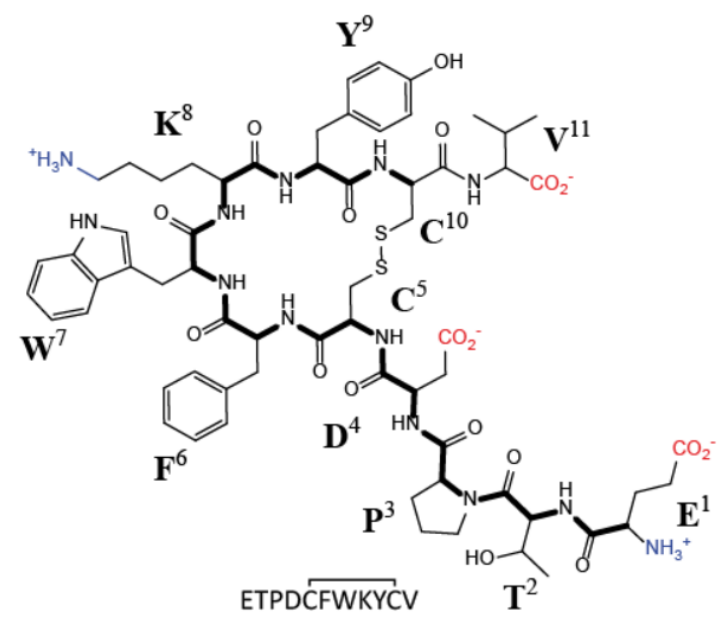

b

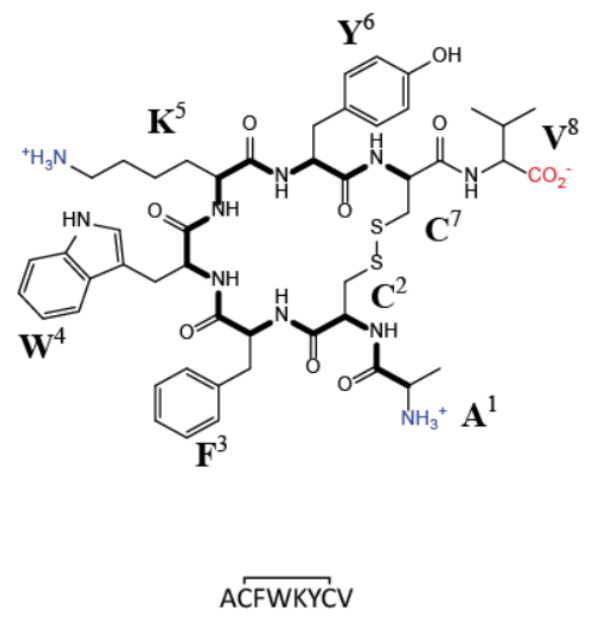

Scheme 1. a) Human Urotensin II (UII) and b) Urotensin Related Peptide (URP) 
Although UII and URP show similar potency at the UTR ${ }^{12,15,16}$ and apparently have overlapping binding sites, ${ }^{17}$ their signaling outcomes may, nevertheless, differ. ${ }^{13}$ UII can behave as an almost irreversible UTR agonist, and the two peptides can affect astrocyte activity differently. ${ }^{18,19}$ The effects of UII or URP are often not conserved across species ${ }^{11,20}$ and may even be opposite (vasoconstrictive and vasodilative) within the same species. ${ }^{21}$ In summary, the urotensinergic system is far from being well understood. Multiallosteric interactions of receptor and ligands or biased agonism that ultimately trigger different functions have been hypothesized..$^{22}$

Biological activity studies have shown that the ring sequence $\mathrm{UII}_{(4-11)}$ is necessary to retain full agonistic potency ${ }^{16,23}$ and that the motif is essential for receptor activation. ${ }^{23,24}$ An intact bridge also seems essential ${ }^{16,25,26}$ but need not be a disulfide. ${ }^{25}$ However, recently, the first acyclic peptide agonist for UTR has been described, a UII analog still suggesting WKY as receptor activating motif. ${ }^{27}$ Nuclear magnetic resonance (NMR) studies in water $^{24,}{ }^{28}$ and dimethyl sulfoxide, ${ }^{29}$ supported by circular dichroism (CD) spectroscopy, ${ }^{28}$ have been interpreted to indicate an unstructured form for human UII with no classical turns or intramolecular hydrogen bonds. However, Lescot et al. ${ }^{30}$ inferred, from NMR studies, a widened 7,8,9 $\gamma$-turn and a 8,9,10 $\gamma$-turn with close $\mathrm{W}^{7} \mathrm{O}-\mathrm{Y}^{9} \mathrm{H}^{\mathrm{N}}$ and $\mathrm{K}^{8} \mathrm{O}-\mathrm{C}^{10} \mathrm{H}^{\mathrm{N}}$ distances for the human UII conformation in water, thus localizing a turn center in the ring at residues $\mathrm{K}^{8}$ and $\mathrm{Y}^{9}$. All NMR investigations show the N-terminal tail to be more flexible than the ring. URP has been suggested from the NMR experiments by Chatenet et al. ${ }^{15}$ to have an inverse 4,5,6 $\gamma$-turn centered at $\mathrm{K}^{5}$ in water with the intramolecular hydrogen bond $\mathrm{W}^{4} \mathrm{O}-\mathrm{Y}^{6} \mathrm{H}^{\mathrm{N}}$. NMR experiments by Brancaccio et al., ${ }^{31}$ however, suggest structural flexibility in aqueous solution and a high similarity of URP and UII ring conformations. Carotenuto et al. ${ }^{28}$ made NMR studies of UII and the smaller URP-like version, $\mathrm{UII}_{(4-11)}$, in sodium dodecyl sulfate (SDS) micelles mimicking a cell-surface environment. They found two slowly exchanging states: one specified as $\beta$-hairpin with a $\beta$-turn type II' centered at $\mathrm{W}^{7}$ and $\mathrm{K}^{8}$ and another weakly populated, 
apparently, with a more flexible and random structure. The highly structured state was suggested to be the active conformation in the receptor-binding pocket. Analogous experiments for URP in SDS micelles suggested a very similar structure. ${ }^{31}$

We now report unrestrained molecular dynamics (MD) simulations of human UII and URP with the Amber ff99sb force field on extended time scales (see Table S1 and Figures S1-S6 of the Supporting Information, SI). These simulations are designed to investigate the conformational space of the peptides as completely as possible. To rule out small force-field artifacts that might become important for such small peptides, we have also performed additional unrestrained microsecond-scale MD simulations with the CHARMM c36b2 force field. These simulations revealed no significant difference between the conformations obtained with the two force fields, so that we concentrate on the AMBER results, which are more extensive. Replica-exchange molecular dynamics (REMD) simulations have been used to improve the conformational sampling and to obtain thermodynamic information. The results are compared with NMR-spectroscopic experiments and a statistical model of the conformational equilibrium in aqueous solution is given.

\section{Methods}

Molecular dynamics simulations. MD simulations of the peptides UII and URP were performed with Amber 10, ${ }^{32,} 33$ Amber 14 CUDA, ${ }^{34-37}$ and CHARMM c36b2. ${ }^{38}$ Amber calculations used the ff99SB force field. ${ }^{39}$ Comparison simulations with CHARMM parameter set $36^{38}$ were used to rule out force-field artefacts. REMD simulations were performed with Amber. All simulations were carried out with unrestrained distances and explicit water solvation. Further simulation details are given in the SI (pp S2-S7).

Conformational analysis. Conformational clustering of the backbone dihedrals (overall states) was performed with DASH. ${ }^{40,}{ }^{41}$ Additional sub-clustering of the ring and tail conformations led to a classification of UII and URP conformations in terms of distinct ring- 
state types. As representatives, the overall conformations of highest similarity to each ring-state type were chosen, equivalent to cluster centers (Table S2). Hydrogen-bond populations and secondary structure motifs of characteristic conformations were calculated from corresponding sections of the MD trajectories using AmberTools with default settings. ${ }^{33,} 34,42$ Consistency of type assignments of states from different simulations was ensured by comparing the circular similarities of ring torsions, turn propensities and $\mathrm{C}^{\alpha}$ alignments. Further details are given in the SI (p S8).

Principal component analysis. A possible correlation of ring and tail motions was analyzed with principal component analysis (PCA) implemented in DASH. ${ }^{41}$ Torsion weights were calculated from the coefficients of the relevant principal components (PCs). The number of significant PCs was determined by Kaiser's eigenvalue-one test. ${ }^{43} \mathrm{PC}$ clustering was visualized via 3D-scatter plots of the three most significant principal components color-coded according to the assigned DASH states in SAR-caddle. ${ }^{44}$ Further details are given in the SI (p S2-13).

NMR. NMR spectra were recorded for human UII and URP at $\mathrm{pH} 3.0 / 3.5$ and $\mathrm{pH} 6.0$ in $\mathrm{H}_{2} \mathrm{O}$ and $\mathrm{D}_{2} \mathrm{O}$ on a Varian Inova $600 \mathrm{MHz}$ spectrometer. Proton resonance assignments were achieved using $2 \mathrm{D}{ }^{1} \mathrm{H}-{ }^{1} \mathrm{H}$ total chemical shift correlation spectroscopy (TOCSY) ${ }^{45}$ and ${ }^{1} \mathrm{H}-{ }^{1} \mathrm{H}$ nuclear Overhauser effect spectroscopy (NOESY) NMR spectra. ${ }^{46}$ Resonance assignments of carbon and nitrogen at natural abundance were achieved through standard ${ }^{13} \mathrm{C}-{ }^{1} \mathrm{H}$ gradient heteronuclear single quantum coherence (gHSQC) and ${ }^{15} \mathrm{~N}-{ }^{1} \mathrm{H}$ gHSQC experiments. ${ }^{47-49}$ Details of sample preparation and NMR experiments are given in the SI (pp S14-18).

Density-functional theory (DFT) calculations on representative conformations. The geometries of representative conformations for UII and URP derived from the DASH analysis were first optimized at the B3LYP $50-53 / 6-31 \mathrm{G}(\mathrm{d})^{54-58}$ level with Gaussian 09, Revision C.01.59 Water solvation was simulated with the default Polarizable Continuum Model (PCM) using the integral equation formalism variant (IEFPCM)). ${ }^{60}$ The DFT-optimized structures were then used to calculate the magnetic shielding tensors in solution at the same level of theory and 
converted to ${ }^{1} \mathrm{H},{ }^{13} \mathrm{C}$, and ${ }^{15} \mathrm{~N}$ chemical shifts using regression formulas based on standard sets of chemical shifts and calculated values. The regression formulae and calculated chemical shifts are given in the SI (pp S19-23, Figure S7, Tables S9-S11).

Equilibrium models and experimental evaluation. Free energies and relative populations (equilibrium models) for the representative conformations of UII and URP were calculated from extended REMD simulations. For each peptide, three simulations of $500 \mathrm{~ns}$ were performed starting from different initial conformations (UII: omega-Iopen, folded-I, lasso; URP:

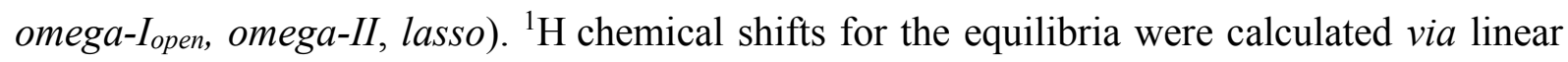
combination of the calculated shifts for the representative conformations according to the populations suggested by REMD. The calculated shifts of representatives and conformational equilibria were then compared by linear regression with our experimental data for nonexchangeable ${ }^{1} \mathrm{H}$ chemical shifts of UII and URP in aqueous solution at $\mathrm{pH} 6.0$ and $\mathrm{pH} 3.5$, respectively.

We have recently published details of chemical-shift comparisons for the closely related vasopressin and have suggested statistical metrics for judging whether conformational equilibria suggested by simulations are consistent with experiment. ${ }^{61}$ Here, we used REMD to determine equilibrium populations, rather than the metadynamics. This substitution is tested here.

Further details are given in the SI (pp S24-S28, Figures S8-S9, Table S13-S15).

\section{Results and discussion}

Conformations of Urotensin II. In total, $35 \mu$ s of unrestrained MD simulations with the Amber ff99SB force field supplemented with $1.3 \mu$ s CHARMM c36b2 trajectories were used to explore the conformational space of UII (Tables S1-S2 of the SI). The conformational analysis led to the classification summarized in Table 1. UII exhibits two main types of ringstates, unfolded open and saddle-like folded ring conformations, which are subdivided into a 
total of 11 subtypes, each defined by its main turn center. Secondary structure propensities and populations of transannular hydrogen bonds are given in Table 2 and 3.

Open ring-state types. Turns in this class are centered at residues $\mathrm{K}^{8} \mathrm{Y}^{9}$ or $\mathrm{F}^{6} \mathrm{~W}^{7}$ (Table 3) with turns fluctuating around ideal $\beta$-turn angles (Table S3 of the SI). The majority of these turns have no or only sparsely populated transannular $\mathrm{O}_{\mathrm{i}-\mathrm{H}_{\mathrm{i}+3}}$ hydrogen bonds (Table 2). Only type scoop $(6,7 \beta-\mathrm{I})$ and omega-I hbond $_{\text {( }}(8,9 \beta-\mathrm{I})$ exhibit significant transannular hydrogen-bond populations but the latter frequently interconverts with the open omega-I $I_{\text {open }}$ state $(8,9 \beta$-VIII) resulting in an average population of $44.3 \%$ equivalent to an open turn. Additionally, a ring state was found with no defined $\beta$-turns in the ring (circle), a loop structure closed by hydrogen bond $\mathrm{W}^{7} \mathrm{O}-\mathrm{C}^{5} \mathrm{H}^{\mathrm{N}}$. The interpreted structures based on NMR studies of UII in aqueous solution resemble the open ring-state types (e.g., turn centers at residues $8,9^{22}$ or no transannular hydrogen bonds ${ }^{20}$ ). Furthermore, the open omega conformations of UII show significant similarities to the clinched open states of the related peptide $\operatorname{Arg}^{8}$-vasopressin (AVP) ${ }^{62}$ (Table 4). The clinched open conformation of AVP, however, is only populated approximately $30 \%$ in aqueous solution. ${ }^{61}$

Folded ring-state types. The second main cluster comprises saddle-like ring conformations with multiple turns, centered either at residues $\mathrm{F}^{6} \mathrm{~W}^{7} \mathrm{~K}^{8}$ or $\mathrm{W}^{7} \mathrm{~K}^{8} \mathrm{Y}^{9}$ (Tables 1 and 3). This class shows highly populated transannular hydrogen-bonds that stabilize the folded conformations of the ring (Table 2). Subtype folded-I (turns centered at $\mathrm{W}^{7} \mathrm{~K}^{8} \mathrm{Y}^{9}$ comprising a $7,8 \beta$-I turn) corresponds to the saddle state of AVP; subtype folded-IVb2 (a peptide-bond rotamer of foldedI with a 7,8 $\beta$-II turn) is equivalent to the twisted-saddle state of AVP. Interestingly, for AVP, the folded saddle conformation is the most highly populated in aqueous solution, ${ }^{61,63}$ whereas for UII a folded conformation ( $\beta$-hairpin centered at $\mathrm{W}^{7} \mathrm{~K}^{8}$ ) has only been identified experimentally in SDS micelles. ${ }^{28}$ The SDS conformation resembles the folded conformations found in our MD simulations. 


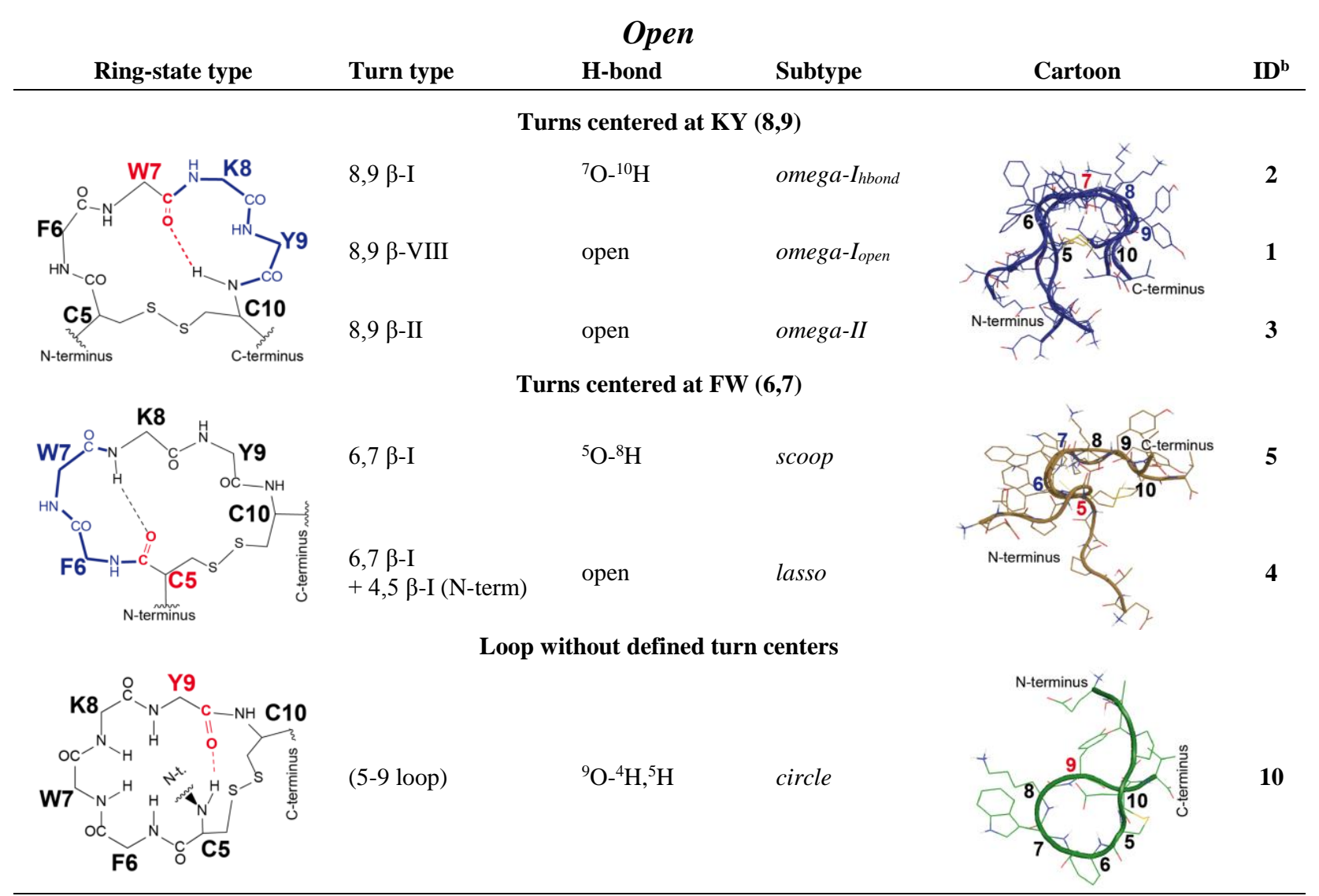

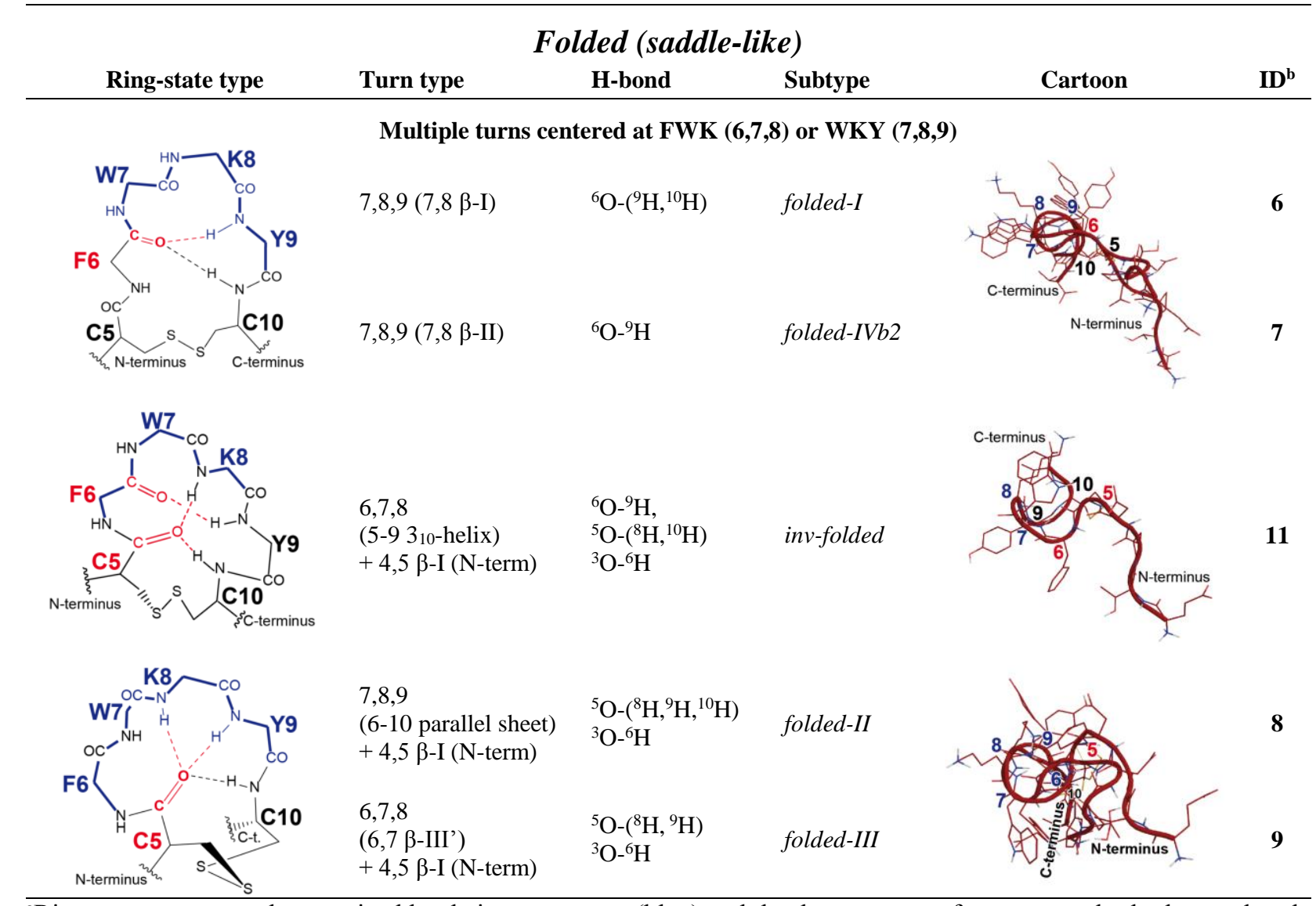

${ }^{\mathrm{a}}$ Ring-state types are characterized by their turn centers (blue) and the donor oxygen for transannular hydrogen-bond interactions (red). Side chains are indicated by the 1-letter code of the residue. Turn types and corresponding hydrogen bonds populated $>70 \%$ are listed. ${ }^{b}$ Mean torsion angles (Table S3) and coordinate files of representatives are given in the SI (ID = ID of representative). 
Table 2. Hydrogen-Bond Populations ${ }^{\mathrm{a}}$ and Corresponding Turn Centers of UII Ring-State Types

\begin{tabular}{|c|c|c|c|c|c|c|c|c|c|}
\hline \multicolumn{2}{|c|}{$\begin{array}{c}\text { Hydrogen } \\
\text { bonds }\end{array}$} & \multicolumn{7}{|c|}{ Conformation (ring-state type) } & \multirow[t]{2}{*}{$\begin{array}{c}\text { Turn } \\
\text { center }\end{array}$} \\
\hline \multicolumn{9}{|c|}{ Open } & \\
\hline & & $\Omega-I_{\text {hbond }}$ & $\Omega-I_{\text {open }}$ & $\Omega-I_{a v}{ }^{b}$ & $\Omega-I I$ & lasso & scoop & circle & \\
\hline $\mathrm{W}^{7} \mathrm{O}$ & $\mathrm{C}^{10} \mathrm{H}$ & 88.1 & 18.8 & 44.3 & 6.0 & 0.0 & 0.0 & 0.0 & 8,9 \\
\hline $\mathrm{C}^{5} \mathrm{O}$ & $\mathrm{K}^{8} \mathrm{H}$ & 0.0 & 0.0 & 0.0 & 0.0 & 12.4 & 73.8 & 0.0 & 6,7 \\
\hline $\mathrm{W}^{7} \mathrm{O}$ & $\mathrm{Y}^{9} \mathrm{H}$ & 9.8 & 8.5 & 9.9 & 0.0 & 0.7 & 70.4 & 0.0 & 8 \\
\hline $\mathrm{Y}^{9} \mathrm{O}$ & $\mathrm{C}^{5} \mathrm{H}$ & 0.0 & 0.0 & 0.0 & 0.0 & 0.0 & 0.0 & 96.3 & (9-5 loop) \\
\hline $\mathrm{Y}^{9} \mathrm{O}$ & $\mathrm{D}^{4} \mathrm{H}$ & 0.0 & 0.0 & 0.0 & 0.0 & 0.0 & 0.0 & 92.4 & (9-4 loop) \\
\hline \multicolumn{10}{|c|}{ Folded } \\
\hline & & folded-I & folded-IVb2 & & ded & folded-II & & olded-III & \\
\hline $\mathrm{F}^{6} \mathrm{O}$ & $\mathrm{Y}^{9} \mathrm{H}$ & 95.8 & 73.9 & & & 0.0 & & 0.1 & 7,8 \\
\hline $\mathrm{F}^{6} \mathrm{O}$ & $\mathrm{C}^{10} \mathrm{H}$ & 63.6 & 10.5 & & & 0.0 & & 0.1 & $7,8,9$ \\
\hline $\mathrm{C}^{5} \mathrm{O}$ & $\mathrm{K}^{8} \mathrm{H}$ & 0.0 & 2.4 & & & 77.2 & & 83.7 & 6,7 \\
\hline $\mathrm{C}^{5} \mathrm{O}$ & $\mathrm{Y}^{9} \mathrm{H}$ & 0.0 & 0.1 & & & 99.4 & & 98.2 & $6,7,8$ \\
\hline $\mathrm{C}^{5} \mathrm{O}$ & $\mathrm{C}^{10} \mathrm{H}$ & 0.0 & 0.0 & & & 89.3 & & 0.3 & $(5-10)$ \\
\hline $\mathrm{P}^{3} \mathrm{O}$ & $\mathrm{F}^{6} \mathrm{H}$ & 0.9 & 0.2 & & & 84.3 & & 85.1 & 4,5 \\
\hline $\mathrm{T}^{2} \mathrm{O}$ & $\mathrm{W}^{7} \mathrm{H}$ & 0.0 & 0.0 & & & 0.0 & & 61.6 & $(2-7)$ \\
\hline
\end{tabular}

${ }^{a}$ Hydrogen-bond populations are relative to the lifetime of the ring state type; only those hydrogen bonds are listed that were found to be populated $>50 \%$ for at least one ring state subtype; hydrogen bonds $>70 \%$ (presumably involved in classical turns) are shown in bold. ${ }^{\mathrm{b}}$ Average hydrogen-bond population for the frequently interconverting sub-types $\Omega-\mathrm{I}_{\mathrm{hbond}}$ and $\Omega-\mathrm{I}_{\mathrm{open}}$ (cf. Figure $\mathrm{S} 1$ of the $\left.\mathrm{SI}\right) ; \Omega=$ omega.

Table 3. Secondary Structure Populations (\%) for Ring-State Types of UII

\begin{tabular}{|c|c|c|c|c|c|c|c|c|c|c|}
\hline \multicolumn{11}{|c|}{ UII } \\
\hline \multirow{2}{*}{ Ring-state type } & \multicolumn{9}{|c|}{ Residue $^{\mathbf{a}}$} & \multirow{2}{*}{ Motif $^{\prime}$} \\
\hline & $\mathbf{T}^{2}$ & $\mathbf{P}^{3}$ & $\mathrm{D}^{4}$ & $C^{5}$ & $F^{6}$ & $\mathbf{W}^{7}$ & $\mathbf{K}^{8}$ & $\mathrm{Y}^{9}$ & $\mathbf{C}^{10}$ & \\
\hline \multicolumn{11}{|c|}{ Open } \\
\hline omega-I $I_{\text {open }}$ & 0.00 & 1.21 & 1.24 & 0.66 & 0.62 & 0.12 & 27.12 & 27.16 & 1.23 & $\mathrm{~T}$ \\
\hline omega-I I & 0.00 & 24.14 & 24.15 & 0.02 & 0.00 & 0.00 & 77.96 & 78.51 & 25.05 & $\mathrm{~T}$ \\
\hline omega-I Ivverage $_{\text {. }}$ & 0.10 & 4.46 & 4.52 & 0.17 & 0.02 & 0.00 & 47.41 & 47.71 & 15.95 & $\mathrm{~T}$ \\
\hline omega-II & 0.35 & 2.22 & 1.88 & 0.02 & 0.02 & 0.00 & 48.69 & 48.70 & 0.52 & $\mathrm{~T}$ \\
\hline scoop & 0.00 & 3.04 & 3.04 & 0.00 & 86.91 & 86.94 & 0.15 & 7.79 & 7.79 & $\mathrm{~T}$ \\
\hline lasso & 0.00 & 0.05 & 53.99 & 56.26 & 21.61 & 18.36 & 1.92 & 1.49 & 0.00 & $\mathrm{~T}$ \\
\hline circle & 0.00 & 0.00 & 0.00 & 0.00 & 0.00 & 0.00 & 0.00 & 0.00 & 0.00 & $\mathrm{~T}$ \\
\hline \multicolumn{11}{|c|}{ Folded } \\
\hline folded-I & 1.02 & 10.04 & 11.83 & 2.50 & 0.09 & 75.10 & 75.22 & 67.70 & 3.20 & $\mathrm{~T}$ \\
\hline folded-IVb2 & 0.00 & 4.96 & 5.22 & 0.29 & 0.51 & $\mathbf{7 8 . 7 8}$ & 86.33 & 68.73 & 9.36 & $\mathrm{~T}$ \\
\hline \multirow[t]{2}{*}{ inv-folded } & 0.00 & 2.14 & 59.19 & 59.19 & 5.83 & 6.84 & 7.84 & 99.97 & 89.60 & $\mathrm{~T}$ \\
\hline & 0.00 & 0.54 & 20.44 & 23.31 & 92.64 & 93.16 & 92.15 & 0.00 & 0.00 & $\mathrm{H}$ \\
\hline \multirow[t]{2}{*}{ folded-II } & 0.00 & 0.00 & 95.07 & 95.07 & 42.71 & 100.00 & 100.00 & 98.87 & 0.00 & $\mathrm{~T}$ \\
\hline & 0.00 & 0.00 & 0.00 & 0.00 & 57.29 & 0.00 & 0.00 & 0.00 & 56.47 & $\mathrm{P}$ \\
\hline folded-III & 24.93 & 43.33 & 63.97 & 64.83 & 99.90 & 99.65 & 99.69 & 13.04 & 0.44 & $\mathrm{~T}$ \\
\hline
\end{tabular}

${ }^{a}$ Populations $>75 \%$ (classical turns) and $>25 \%$ (potentially open turn) are shown in bold and italics, respectively (for notation of secondary structure elements, see $\mathrm{SI}){ }^{\mathrm{b}} \mathrm{T}=$ turn, $\mathrm{P}=$ parallel sheet, $\mathrm{H}=3_{10}$-helix. 
Table 4. Similarity of Ring Torsions of $\mathrm{UII}_{(5-10)}, \mathrm{URP}_{(2-8)}$, and $\operatorname{AVP}_{(1-6)}$ a

\begin{tabular}{|c|c|c|c|c|c|c|c|}
\hline \multicolumn{3}{|c|}{ Conformation (ring-state type) } & \multicolumn{2}{|c|}{ Circular similarity $^{\mathrm{c}}$} & \multicolumn{3}{|c|}{ Turn type } \\
\hline UII & URP & AVP & UII/URP & UII/AVP & UII & URP & AVP \\
\hline \multicolumn{8}{|c|}{ Open } \\
\hline 1 omega-I $I_{\text {open }}$ & $3 \mathbf{r}$ omega-I Iopen & 12 cl.open & 0.95 & 0.88 & $8,9 \beta$-VIII & $5,6 \beta$-VIII & $4,5 \beta-\mathrm{VIII}_{\mathrm{dis}} / \mathrm{I}$ \\
\hline 2 omega-Ihbond & 1r omega-I hbond & 12 cl.open & 0.99 & 0.83 & $8,9 \beta-\mathrm{I}$ & $5,6 \beta-\mathrm{I}$ & $4,5 \beta-$ VIII $_{\text {dist }} / \mathrm{I}$ \\
\hline 3 omega-II & $2 \mathbf{r}$ omega-II & - & 0.93 & - & $8,9 \beta$-II & $5,6 \beta$-II & $4,5 \beta$-II \\
\hline 4 lasso & 6r $\quad$ (lasso45pr) & 27 open & $0.55^{\mathrm{d}}$ & $0.55^{\mathrm{e}}$ & $6,7 \beta-\mathrm{I}$ & $3,4 \beta-$ VIII dist $_{\text {dist }}$ & 2,3 \\
\hline 5 scoop & - & - & - & - & $6,7 \beta-\mathrm{I}$ & - & - \\
\hline 10 circle & - & - & - & - & (5-9 loop) & - & - \\
\hline \multicolumn{8}{|c|}{ Folded } \\
\hline 6 folded-I & -- & 3 saddle & - & 0.93 & 7,8,9 (7,8 $\beta-\mathrm{I})$ & - & $3,4,5(\beta-\mathrm{I})$ \\
\hline 7 folded-IVb2 & 4r hybrid & 19 tw.saddle & 0.89 & 0.95 & $7,8,9(7,8 \beta-I I)$ & $4,5,6 \gamma$ & $3,4,5$ ( $\beta$-II) \\
\hline & $\mathbf{5 r}$ sheet & - & 0.67 & - & - & 4,5 (ap.sheet $\beta$-II) & - \\
\hline 11 inv-folded & $-\quad-$ & - & - & - & $6,7,8\left(3_{10}\right.$-helix $)$ & - & - \\
\hline 8 folded-II & -- & - & - & - & $7,8,9$ (p.sheet) & - & - \\
\hline 9 folded-III & - & - & - & - & $6,7,8$ (6,7 $\beta$-III') & - & - \\
\hline \multicolumn{8}{|c|}{ 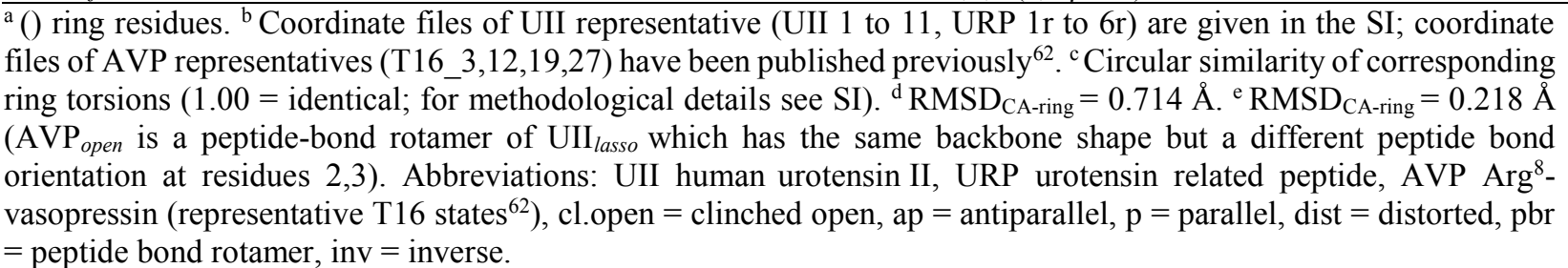 } \\
\hline
\end{tabular}

\section{Are Tail and Ring Conformation of Urotensin II Mutually Dependent?}

As described above, the structure of UII can be characterized by its ring conformation and by treating the N-terminus as an additional residue. A principal-component analysis (PCA) of the overall torsion space supports this approach. It clusters the overall conformations of UII in accordance to the ring-state types clustered with $\mathrm{DASH}^{40}$ (Figure 1). Nevertheless, the tail remains of special interest as it is the only structural difference between UII and URP. DASH clustering (Figures S1-S6 of the SI) reveals that the basic conformation of the N-terminal tail is extended or folded with the majority of folded tail-conformations caused by a single turn centered at either $\mathrm{P}^{3} \mathrm{D}^{4}$ or $\mathrm{D}^{4} \mathrm{C}^{5}$ of turn types $\beta$-I/VIII or II, as shown in Figure 2. 


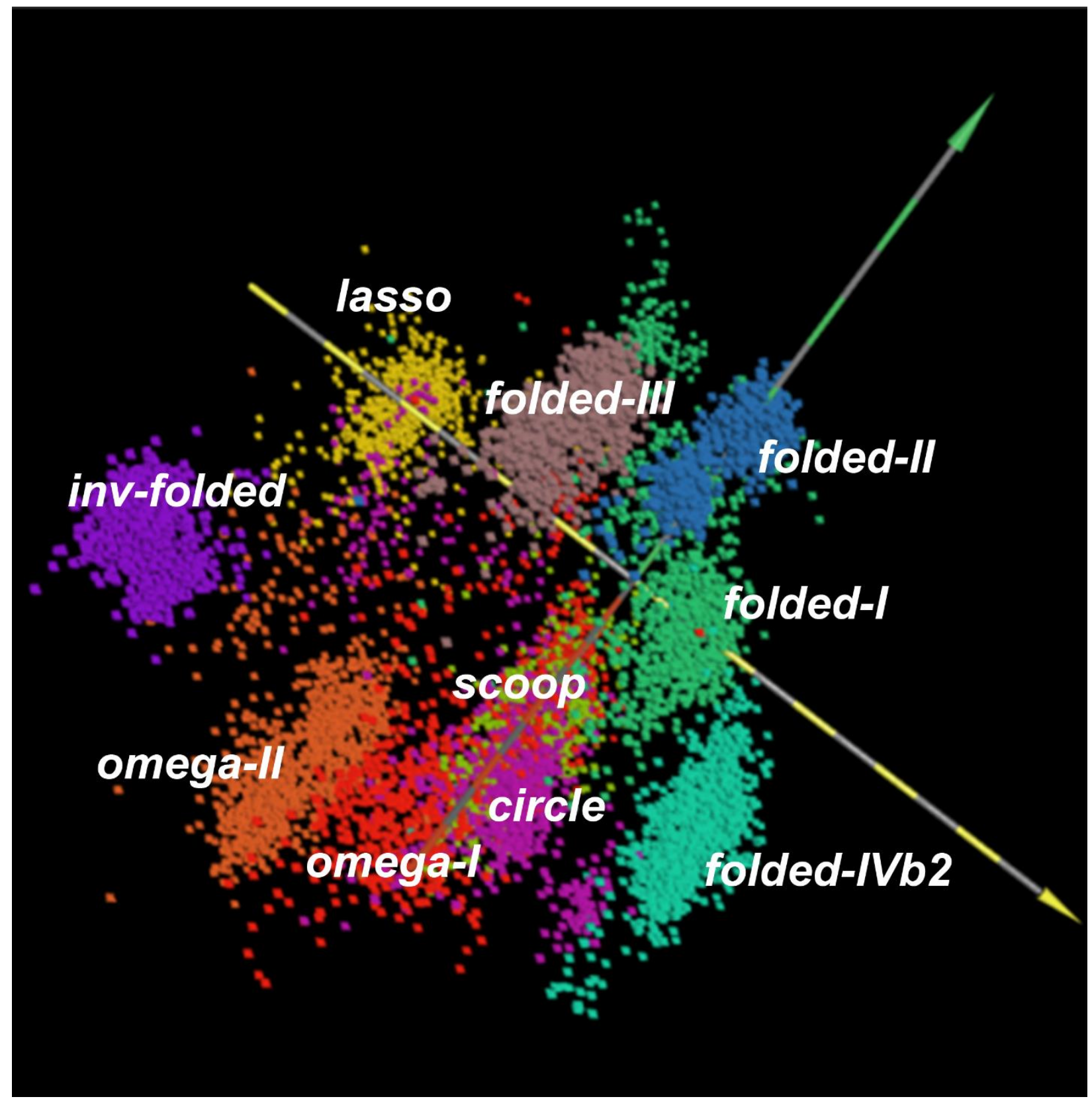

Figure 1. PCA clusters of UII conformations (3D-scatter plot of the three main PCs of the overall backbone torsion space of UII). Each dot represents a conformational snapshot of UII from the MD simulations. Conformations are color-coded by DASH ring-state types. PCA confirms that DASH clustering of ring conformations is suitable for characterizing the overall structure of UII. 


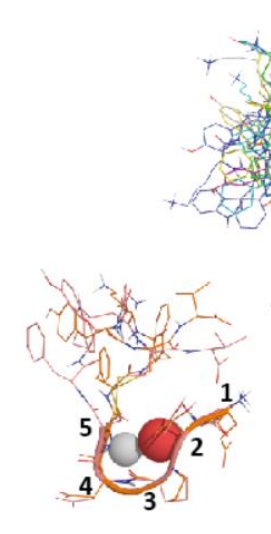

B 3,4 B-turn I/II

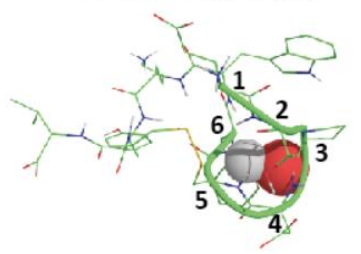

multiple turn

D 4,5 ß-turn I + 2,3
A extended

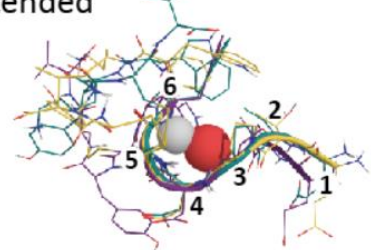

C 4,5 ß-turn I/VIII/II

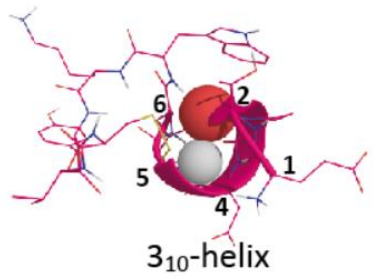

E 2 to 5

Figure 2. Tail-state types of urotensin II. Hydrogen and oxygen atoms of hydrogen bonds are represented as spheres.

The relative populations of extended and folded tail states in the MD simulations vary significantly (cf. Figures S1-S6 of the SI). Some ring-state types show frequent interconversions of extended and folded tail states, others none or few; and the extended:folded ratio for some types is not consistent between simulations. This raises the question as to whether tail and ring states might be mutually dependent. A qualitative answer is given by analyzing the weights of ring and tail torsions of the main significant PCs for each type of ring conformation (Table S4). If both ring and tail torsions are significantly loaded on one PC, correlation can be assumed. The results are summarized in Table 5. Few ring state types (folded-I and folded-IVb2) show unambiguously that ring and tail torsions are not correlated, whilst omega-I types show uncorrelated ring/tail motions only if the tail is exclusively extended (Figure S1). For all other types, the PCA results suggest interdependence of ring and tail conformations. This contrasts with AVP, where the tail (the three 
bond populations at $\mathrm{Y}^{4} \mathrm{O}-\mathrm{C}^{7} \mathrm{H}^{\mathrm{N}}$ and turn propensities at $\mathrm{K}^{5} \mathrm{Y}^{6}$ of URP's omega type resemble the data of the corresponding UII conformations (Tables 2 and 3). Conformations with turns different to $\mathrm{K}^{5} \mathrm{Y}^{6}$ are only found as transient states with low absolute populations. There is a variant of the UII lasso type with a type VIII $\beta$-turn centered at $\mathrm{F}^{3} \mathrm{~W}^{4}$. Two further transient states are comparable with the folded conformations of UII. One (denoted as sheet) forms an antiparallel $\beta$-sheet with a $\beta$-II turn at $\mathrm{W}^{4} \mathrm{~K}^{5}$, the other (denoted as hybrid) exhibits a $\gamma$-turn at $\mathrm{W}^{4} \mathrm{~K}^{5} \mathrm{Y}^{6}$ and shows $89 \%$ similarity to the ring torsions of the folded-IVb2 state of UII. The sheet type resembles the postulated single-conformer structure of URP in SDS micelle solution. ${ }^{31}$ The hybrid type is reminiscent of Chatenet's NMR-based single-conformer description of URP in aqueous solution. ${ }^{15}$ 
Table 6. Classification of Ring Conformations of URP ${ }^{a}$

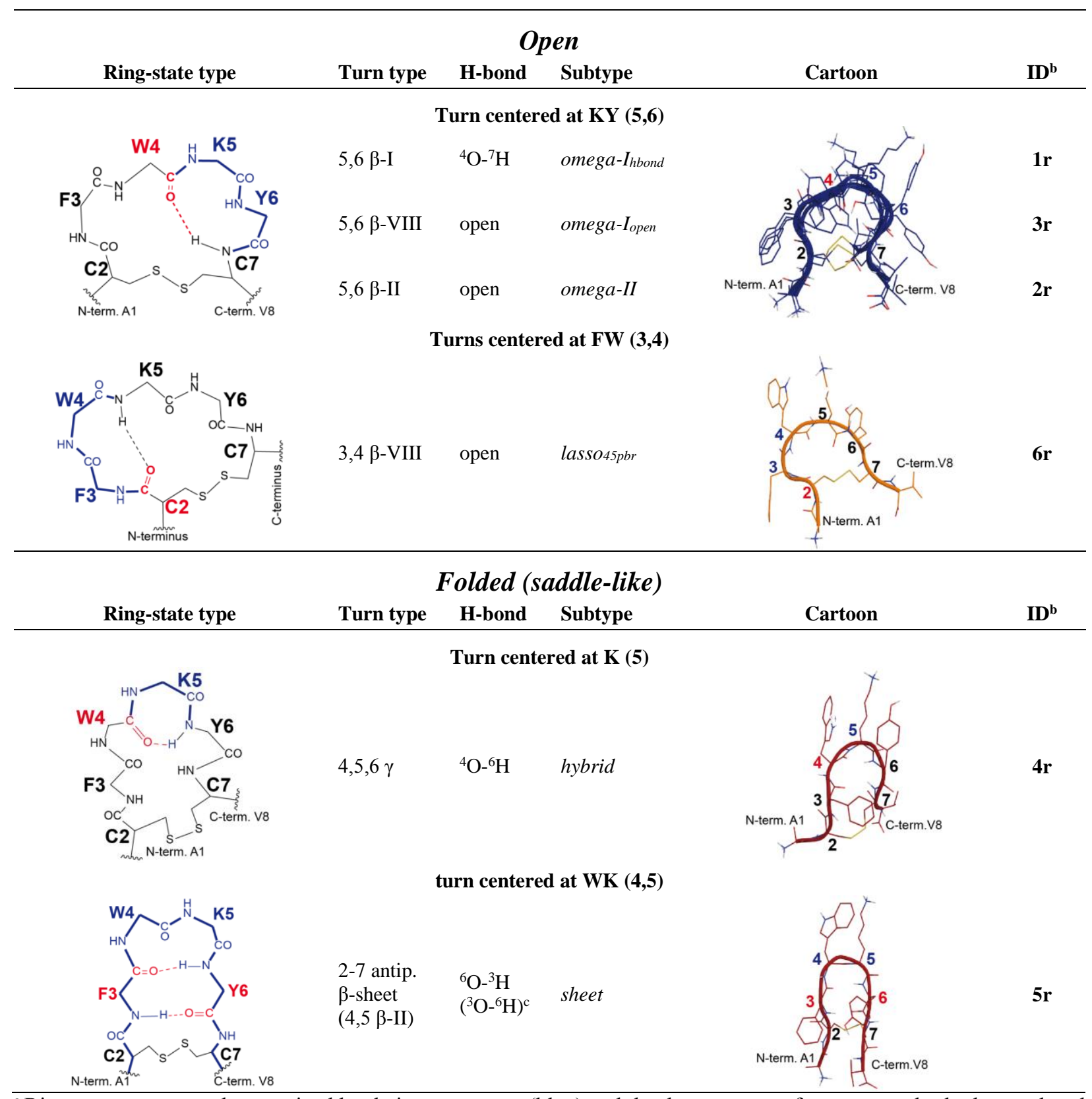

${ }^{a}$ Ring-state types are characterized by their turn centers (blue) and the donor oxygen for transannular hydrogen-bond interactions (red). Side chains are indicated by the single-letter code of the residue. Turn types and corresponding hydrogen bonds populated $>70 \%$ are listed. ${ }^{b}$ Mean torsion angles (Table S3) and coordinate files of representatives are given in the SI (ID = ID of representative). ${ }^{c} 48 \%$ population. 


\section{Determination of UII and URP Equilibrium Populations.}

Most of the ring-state types described above exhibit significant lifetimes during MD simulation and, therefore, represent candidates for the main conformations in solution. However, interconversions are too infrequent to derive equilibrium populations directly from the MD simulations. We therefore performed extended REMD simulations of UII and URP to determine the relative population of the states and, hence, to calculate their free energies. NMR experiments were carried out to validate these in silico equilibria via comparison of calculated and experimental chemical shifts using the statistical metrics reported previously. ${ }^{61}$

\section{NMR Experiments.}

${ }^{1} \mathrm{H},{ }^{13} \mathrm{C}$, and ${ }^{15} \mathrm{~N}$ chemical shifts could be assigned for UII and URP in $\mathrm{H}_{2} \mathrm{O}$ at $\mathrm{pH} 3.0 / 3.5$ and 6.0, with the exception of $\mathrm{C}$ and $\mathrm{N}$ atoms without directly bonded protons and some rapidly exchangeable $\mathrm{H}^{\mathrm{N}}$ atoms at $\mathrm{pH}$ 6.0. Our ${ }^{1} \mathrm{H}$ chemical shifts of UII and URP agree well with those already published ${ }^{15,28,30,31}$ and are complemented by our results for ${ }^{13} \mathrm{C}$ and ${ }^{15} \mathrm{~N}$ shifts at the different $\mathrm{pH}$ values. The experimental shift lists are given in the SI (Tables S5-S8). The $\mathrm{pH}$ was varied to see if changing the protonation state induces significant conformational changes. A change to acidic $\mathrm{pH}$ values protonates charged carboxylic acid-containing residues $\left(\mathrm{E}^{1}, \mathrm{D}^{3}\right.$, and the $\mathrm{C}$-terminal $\mathrm{V}^{11}$ in UII; the $\mathrm{C}$-terminal $\mathrm{V}^{8}$ in URP) and this can affect the local electronic structure, as seen by changes in NMR chemical shifts of these residues and their immediate neighbors. The UII peptide is more affected by $\mathrm{pH}$, changing its protonation state from -1 at $\mathrm{pH}$ 6.0 to +2 at $\mathrm{pH} 3.0$, whereas URP only changes from +1 at $\mathrm{pH} 6.0$ to +2 at $\mathrm{pH} 3.0$. However, these $\mathrm{pH}$-dependent changes are small compared to those that occur if the solvent is changed from water 
to an SDS micelle containing aqueous solution, with no buffer added. ${ }^{28,} 31$ A significant conformational change such as that found in SDS micelles ${ }^{28,31}$ can be excluded. Thus, it can be assumed that the most highly populated conformations of UII and URP at $\mathrm{pH} 6.0$ resemble the published NMR structures in aqueous solution. We eschewed a further classical structure determination using experimental nuclear Overhauser effect (NOE) distances or coupling constants and focused on determining conformational equilibrium concentrations via ${ }^{1} \mathrm{H}$ chemical shifts, which proved to be most efficient for vasopressin. ${ }^{61}$ In this context, it is important to note that, while observed NMR chemical shifts represent the time average of the shifts of all structures in a dynamic equilibrium, this is not true of distances derived from NOE peaks. This is because the distance-dependence of the NOE depends on the inverse sixth power $\left(\mathrm{r}^{-6}\right),{ }^{64}$ so that simply averaging the distance (r) will yield incorrect results. Thus, short contacts that occur infrequently can give rise to significant NOE peaks, even though the time-averaged interatom distance may be large. For the same reason, NOE peaks that result from several different conformations in equilibrium can masquerade as a single fictitious conformation. A second set of resonances representing a minor population $(\sim 10 \%$ of the total) was also observed in the UII NMR spectra. This was identified as the $c i s-$ Pro $^{3}$ isomer of UII and fully sequentially assigned. As the cis/trans conversion in peptides is known to be slow on the NMR time scale ${ }^{65,66}$ it will not contribute to fast equilibria and is not discussed here.

\section{Conformational Equilibrium of Urotensin II.}

The relative populations for the representative conformations of UII from three REMD simulations (with different initial conformations) are given in Table 7. This table covers 
approximately $80 \%$ of the conformational REMD snapshots, the remaining $20 \%$ (circular similarity of ring torsions $<65 \%$ ) are transients that cannot be assigned unambiguously to the representatives. All three REMD simulations predict a similar ratio of open to folded conformations and thus, the simulations can be assumed converged for these main conformational types. Unfortunately, the population of the individual subtypes of open and folded has not converged and differs strongly between the three REMD simulations (Table 7). However, convergence would necessitate significantly longer simulation times, which are currently unobtainable.

Table 7. Relative Free Energies $\left.(\Delta \Delta \mathrm{G}, \mathrm{kcal} \mathrm{mol})^{-1}\right)^{\mathrm{a}}$ and Relative Populations (\%) ${ }^{\mathrm{b}}$ of Representative Conformations for UII from REMD Simulations

\begin{tabular}{|c|c|c|c|c|c|c|c|c|c|}
\hline \multirow{2}{*}{\multicolumn{2}{|c|}{ UII representatives }} & \multicolumn{8}{|c|}{ REMD simulations (UII) } \\
\hline & & \multicolumn{2}{|c|}{ REMD-I ${ }^{c}$} & \multicolumn{2}{|c|}{ REMD-II } & \multicolumn{2}{|c|}{ REMD-III } & \multicolumn{2}{|c|}{ stddev $^{d}$} \\
\hline Conformation & ID $^{\mathbf{e}}$ & $\Delta \Delta \mathbf{G}$ & pop\% & $\Delta \Delta \mathbf{G}$ & рор\% & $\Delta \Delta G$ & рор\% & $\Delta \Delta \mathbf{G}$ & рор\% \\
\hline omega-I $I_{\text {open }}$ & 1 & 0.39 & 15.19 & 1.08 & 8.72 & 1.09 & 8.98 & \pm 0.33 & \pm 2.99 \\
\hline omega-I $I_{h b o n d}$ & 2 & 0.41 & 14.76 & 1.45 & 4.68 & 1.19 & 7.69 & \pm 0.44 & \pm 4.22 \\
\hline omega-II & 3 & 1.04 & 5.07 & 2.21 & 1.29 & 1.55 & 4.10 & \pm 0.48 & \pm 1.61 \\
\hline lasso & 4 & 0.00 & 29.75 & 0.00 & 54.11 & 0.00 & 56.73 & \pm 0.00 & \pm 12.15 \\
\hline scoop & 5 & 1.43 & 2.67 & 3.08 & 0.30 & 3.37 & 0.20 & \pm 0.85 & \pm 1.14 \\
\hline circle & 10 & 1.12 & 4.53 & 2.16 & 1.39 & 2.08 & 1.68 & \pm 0.47 & \pm 1.42 \\
\hline \multicolumn{2}{|c|}{ Eopen } & & 72.0 & & 70.5 & & 79.4 & & \\
\hline folded-I & 6 & 1.67 & 1.76 & 1.71 & 3.00 & 2.00 & 1.82 & \pm 0.15 & \pm 0.57 \\
\hline folded-IVb2 & 7 & 2.28 & 0.63 & 3.01 & 0.34 & 3.13 & 0.28 & \pm 0.38 & \pm 0.15 \\
\hline inv.folded & 11 & 0.35 & 16.39 & 1.02 & 9.67 & 0.75 & 15.96 & \pm 0.28 & \pm 3.07 \\
\hline folded-II & 8 & 1.21 & 3.89 & 1.34 & 5.58 & 1.84 & 2.56 & \pm 0.27 & \pm 1.24 \\
\hline folded-III & 9 & 1.02 & 5.37 & 0.95 & 10.92 & - & 0.00 & \pm 0.04 & \pm 4.46 \\
\hline$\Sigma$ folded & & & 28.0 & & 29.5 & & 20.6 & & \\
\hline
\end{tabular}

${ }^{\text {a }}$ Average standard deviation of all $\Delta \Delta \mathrm{G}$ is $0.37 \mathrm{kcal} \mathrm{mol}^{-1}$.

${ }^{\mathrm{b}}$ Total population of assigned representatives: REMD-I $82 \%$, II $77 \%$, III $87 \%$.

${ }^{\mathrm{c}}$ The REMD-I equilibrium gives the best agreement with experiment.

${ }^{\mathrm{d}}$ stddev $=$ standard deviation.

${ }^{\mathrm{e}}$ Coordinate files are available as SI. ID = ID of representative. 
A statistical comparison of the calculated and experimental chemical shifts of UII at $\mathrm{pH} 6$ is given in Table 8. All open:folded equilibria of UII correspond better to the experimental values than any single conformation. The best agreement was found for equilibrium REMD-I, predicting a ratio of $72 \%$ open and $28 \%$ folded conformations for UII in aqueous solution. A plot of the predicted vs experimental shifts is shown in Figure 3. Correlation of calculated and experimental ${ }^{15} \mathrm{~N}$ chemical shifts also confirms the ratio of 72:28 open to folded as the equilibrium that gives the best agreement, although the number of shifts is very small (Table S14 of the SI). The correlation of calculated ${ }^{13} \mathrm{C}$ chemical shifts with experimental shifts is satisfactory for the equilibria but gives the best fit for the omega-Iopen conformations (Table S13 of the SI). However, the correlation within the calculated sets of ${ }^{13} \mathrm{C}$ shifts is too high to give unambiguously distinguishable models (Figure S8). This was also found for $\mathrm{AVP}^{61}$ and is further discussed in the SI.

Smith and Goodman have proposed the so-called DP4-metric, which they designed especially to discriminate between conformations on the basis of the agreement between calculated and experimental NMR chemical shifts. ${ }^{67}$ The DP4 probability is based on Bayes' theorem and is intended to provide an objective assessment of how likely it is that a given diastereomer (or in our case equilibrium distribution of conformations, is correct based on calculated and experimental chemical shifts. In our case the DP4 probabilities for both ${ }^{13} \mathrm{C}$ and ${ }^{1} \mathrm{H}$ shifts help confirm that the chemical shift ensemble resulting from equilibrium REMD-I (72:28) has the highest probability of being a correct assignment (Tables S15 of the SI) in comparison to the single conformations or the equilibria REMD-II and -III. Finally, the dependence of DP4 ("best-fit probability") on variations of the open:folded ratio also results in a clear maximum for an equilibrium at approximately 70:30 (Figure 4), in accordance with our prediction. 
Table 8. Statistical Error Values (ppm), Coefficients of Distinctiveness $\left(\Delta_{\sigma}\right)$, and Determination $\left(\mathrm{R}^{2}\right)$ for the Linear Regression of Calculated and Experimental ${ }^{1} \mathrm{H}$ Chemical Shifts of UII in Aqueous Solution at $\mathrm{pH} 6.0^{\mathrm{a}}$

\begin{tabular}{lcccccc}
\hline UII representatives and equilibria (open:folded) & MSE & MUE & RMSD & WRMSE & $\boldsymbol{\Delta}_{\boldsymbol{\sigma}}$ & $\mathbf{R}^{\mathbf{2}}$ \\
\hline omega- Iopen $_{\text {omega-I }}$ hbond & -0.09 & 0.38 & 0.51 & 0.56 & 1.11 & 0.934 \\
omega-II & -0.02 & 0.31 & 0.42 & 0.46 & 0.99 & 0.956 \\
lasso & 0.03 & 0.33 & 0.43 & 0.46 & 1.02 & 0.953 \\
scoop & 0.03 & 0.29 & 0.35 & 0.38 & 0.96 & 0.968 \\
circle & 0.03 & 0.41 & 0.50 & 0.54 & 1.26 & 0.938 \\
folded-I & 0.00 & 0.30 & 0.40 & 0.42 & 0.95 & 0.962 \\
folded-IVb2 & 0.04 & 0.32 & 0.39 & 0.43 & 1.06 & 0.963 \\
inv-folded & 0.11 & 0.32 & 0.39 & 0.40 & 1.01 & 0.966 \\
folded-II & 0.06 & 0.34 & 0.42 & 0.44 & 1.14 & 0.955 \\
folded-III & 0.05 & 0.40 & 0.49 & 0.55 & 1.15 & 0.936 \\
Equilibrium REMD-I (72:28) & -0.04 & 0.37 & 0.45 & 0.50 & 1.19 & 0.946 \\
Equilibrium REMD-II (70:30) & 0.01 & $\mathbf{0 . 2 1}$ & $\mathbf{0 . 2 6}$ & $\mathbf{0 . 2 7}$ & $\mathbf{0 . 7 5}$ & $\mathbf{0 . 9 8 2}$ \\
Equilibrium REMD-III (79:21) & 0.01 & 0.22 & 0.28 & 0.29 & 0.78 & 0.980 \\
Best resil & 0.02 & 0.23 & 0.29 & 0.30 & 0.81 & 0.979 \\
\hline
\end{tabular}

${ }^{a}$ Best results are shown in bold. MSE $=$ Mean Square Error; MUE $=$ Mean Unsigned Error; RMSD = Root Mean Square Deviation; WRMSE $=$ Weighted Root MSE; $\Delta_{\sigma}=$ coefficient of distinctiveness; ${ }^{61} \mathrm{R}^{2}=$ coefficient of determination
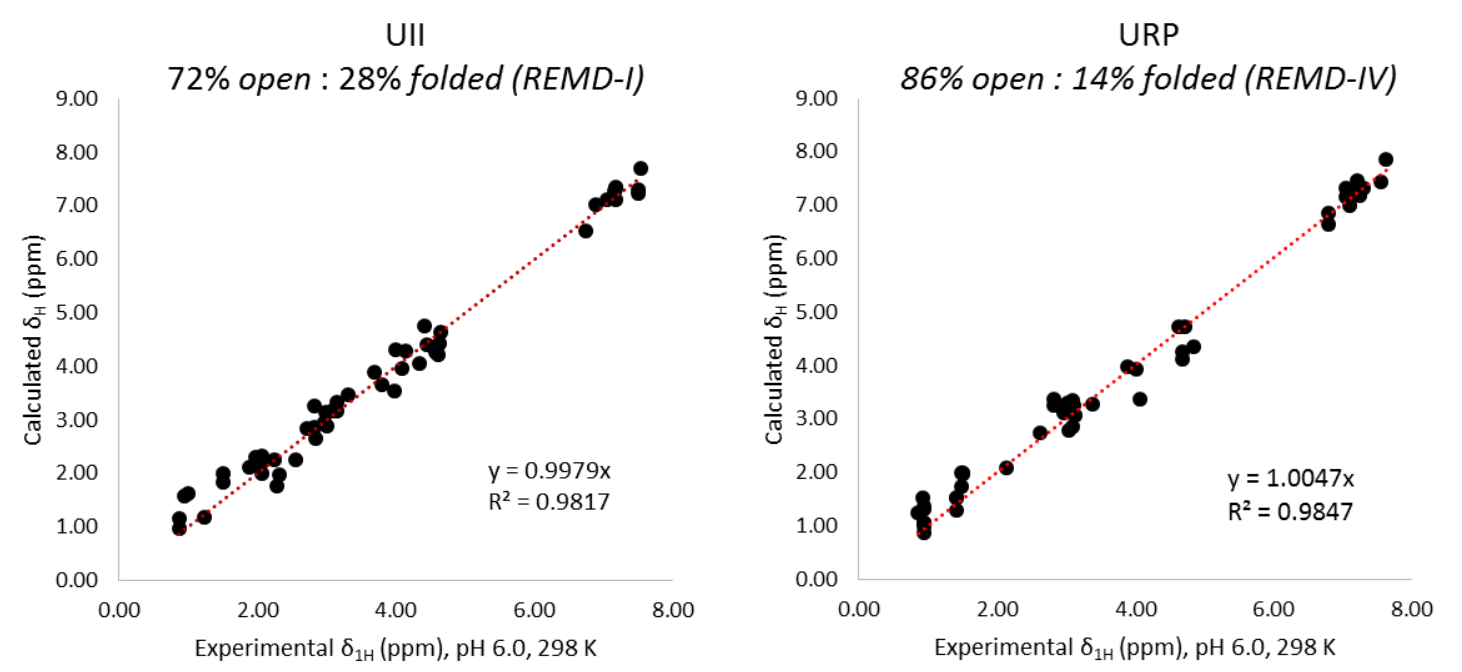

Figure 3. Linear regression of calculated ${ }^{1} \mathrm{H}$ chemical shifts for the best predicted equilibria of open and folded conformations of UII and URP against experimental chemical shifts of nonexchangeable ${ }^{1} \mathrm{H}$ of UII and URP in aqueous solution at $\mathrm{pH}$ 6.0, $298 \mathrm{~K}$. 


\section{UII open:folded sensitivity}

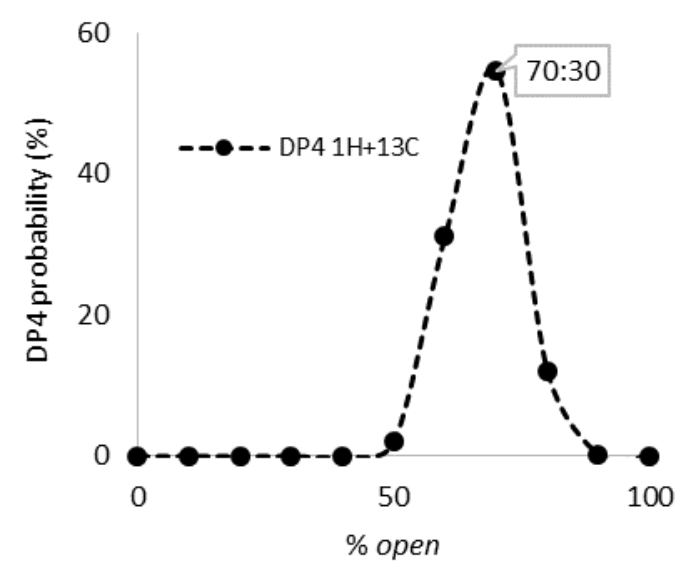

Figure 4. Dependence of DP4 probabilities on the open:folded ratio of UII. Open and folded subtype mixtures correspond to the relative concentrations of the 11-component equilibrium REMD-I. The maximum probability (most likely ratio) is approximately 70:30 open:folded.

Besides the experimental shifts of UII at $\mathrm{pH} 6$, a second set of experimental shifts at $\mathrm{pH} 3$ was measured and compared with the calculated shifts. The statistical metrics (data not shown) are extremely close to those at $\mathrm{pH} 6$ which suggests conformational independence of UII for different protonation states $(+2$ at $\mathrm{pH} 3,-1$ at $\mathrm{pH} 6)$.

The seemingly contradictory experimental single-conformer interpretations of UII's structure in $\mathrm{H}_{2} \mathrm{O}$ (no classical turns ${ }^{28}$ vs widened 7,8,9+8,9,10 $\gamma$-turns ${ }^{30}$ ) are more precisely a fast (on the NMR time scale) equilibrium of major open and minor folded ring conformations, rather than any single conformation. A folded conformation has so far only been proposed from NMR experiments in 
SDS micelles, and was suggested to be the bioactive conformation in the UII receptor (UTR). ${ }^{28}$ Our results indicate that the proposed bioactive folded-type conformations already exist in aqueous solution to a significant extent, hidden in the fast equilibrium and that, if it is the bioactive conformation, it is selected by preferential binding to the receptor from the conformational ensemble.

\section{Conformational Equilibrium of Urotensin Related Peptide.}

Three REMD simulations of URP starting from different initial conformations gave the relative free energies and populations listed in Table 9. The representatives cover approximately $70 \%$ of all REMD conformations. The remaining 30\% (circular similarity of ring torsions $<65 \%$ ) are transient conformations that could not be assigned unambiguously. The overall ratio of open:folded conformations from different REMD simulations are again similar and can be regarded as converged. 
Table 9. Relative Free Energies $\left(\Delta \Delta \mathrm{G}, \mathrm{kcal} \mathrm{mol}{ }^{-1}\right)^{\mathrm{a}}$ and Relative Populations $(\%)^{\mathrm{b}}$ of Representative Conformations for URP from three different REMD Simulations ${ }^{\mathrm{a}, \mathrm{b}, \mathrm{c}}$

\begin{tabular}{|c|c|c|c|c|c|c|c|c|c|}
\hline \multirow{2}{*}{\multicolumn{2}{|c|}{ URP representatives }} & \multicolumn{8}{|c|}{ REMD simulations (URP) } \\
\hline & & \multicolumn{2}{|c|}{ REMD-IV ${ }^{c}$} & \multicolumn{2}{|c|}{ REMD-V } & \multicolumn{2}{|c|}{ REMD-VI } & \multicolumn{2}{|c|}{ stddev $^{d}$} \\
\hline Conformation & ID $^{\mathrm{e}}$ & $\Delta \Delta \mathbf{G}$ & $\%$ & $\Delta \Delta \mathbf{G}$ & $\%$ & $\Delta \Delta \mathbf{G}$ & $\%$ & $\Delta \Delta \mathbf{G}$ & $\%$ \\
\hline omega-I $I_{\text {open }}$ & $3 \mathbf{r}$ & 0.34 & 18.92 & 1.38 & 5.80 & 0.45 & 19.70 & \pm 0.47 & \pm 6.38 \\
\hline omega-I $I_{\text {hbond }}$ & $1 \mathbf{r}$ & 0.08 & 29.73 & 0.49 & 26.09 & 0.33 & 24.24 & \pm 0.17 & \pm 2.28 \\
\hline omega-II & $2 r$ & 0.00 & 33.78 & 0.00 & 59.42 & 0.00 & 42.42 & \pm 0.00 & \pm 10.65 \\
\hline lasso & $6 \mathbf{r}$ & 1.26 & 4.05 & 1.79 & 2.90 & 1.32 & 4.55 & \pm 0.24 & \pm 0.69 \\
\hline Eopen & & & 86.5 & & 94.2 & & 90.9 & & \\
\hline sheet & $5 \mathbf{r}$ & 0.71 & 10.14 & 1.38 & 5.80 & 1.73 & 2.27 & \pm 0.42 & \pm 3.22 \\
\hline hybrid & $4 r$ & 1.36 & 3.38 & - & 0.00 & 1.08 & 6.82 & \pm 0.14 & \pm 2.78 \\
\hline$\Sigma$ folded & & & 13.5 & & 5.8 & & 9.1 & & \\
\hline
\end{tabular}

${ }^{a}$ Average standard deviation $0.29 \mathrm{kcal} \mathrm{mol}^{-1}$. ${ }^{\mathrm{b}}$ Total population of assigned representatives: REMD-IV $74 \%, \mathrm{~V} 69 \%$, VI $66 \% .{ }^{c}$ REMD-IV equilibrium gives the best agreement with experiment. ${ }^{\mathrm{d}}$ stddev $=$ standard deviation. ${ }^{\mathrm{e}}$ Coordinate files are available as SI. ID = ID of representative.

Table 10. Statistical Error Values (ppm), Coefficients of Distinctiveness $\left(\Delta_{\sigma}\right)$ and Determination $\left(\mathrm{R}^{2}\right)$ for the Linear Regression of Calculated and Experimental ${ }^{1} \mathrm{H}$ Chemical Shifts of URP in Aqueous Solution at $\mathrm{pH} 6.0^{\mathrm{a}}$

\begin{tabular}{|c|c|c|c|c|c|c|}
\hline URP representatives and equilibria (open:folded) & MSE & MUE & RMSD & WRMSE & $\Delta_{\sigma}$ & $\mathbf{R}^{2}$ \\
\hline omega-I $I_{\text {open }}$ & -0.02 & 0.27 & 0.37 & 0.43 & 1.02 & 0.9774 \\
\hline omega-I I & -0.09 & 0.32 & 0.44 & 0.55 & 0.99 & 0.9624 \\
\hline omega-II & -0.11 & 0.40 & 0.53 & 0.64 & 1.20 & 0.9456 \\
\hline lasso & -0.08 & 0.41 & 0.52 & 0.64 & 1.26 & 0.9489 \\
\hline sheet & -0.05 & 0.28 & 0.38 & 0.43 & 1.01 & 0.9755 \\
\hline hybrid & -0.01 & 0.33 & 0.44 & 0.53 & 1.12 & 0.9666 \\
\hline Equilibrium REMD-IV (86:14) & -0.08 & 0.22 & 0.29 & 0.31 & 0.78 & 0.9847 \\
\hline Equilibrium REMD-V (94:6) & -0.10 & 0.29 & 0.38 & 0.44 & 0.91 & 0.9723 \\
\hline Equilibrium REMD-VI (91:9) & -0.08 & 0.25 & 0.31 & 0.35 & 0.84 & 0.9815 \\
\hline
\end{tabular}

The model that agrees best with experiment is the equilibrium from REMD-IV (calculated ${ }^{1} \mathrm{H}$ chemical shifts for URP are given in Table S12 of the SI) predicting a ratio of $86 \%$ open and 14\% 
folded conformations for URP with a predominance of omega conformations (Table 10 and Figure 3). This result is further supported by the DP4 assignment probabilities (Tables S15).

Equilibrium REMD-VI also performs better than any single conformation. Only equilibrium REMD-V fits worse than the omega-I $I_{\text {open }}$ conformation. It is noteworthy that the average ratio of the frequently interconverting conformations omega- $I_{\text {open }}$ and omega- $I_{\text {hbond }}$ in the long-scale MD simulations is 42:58. This resembles the relative populations of REMD-IV (39:61) and VI (45:55) but not REMD-V (18:82). Insufficient convergence of the omega-I $I_{\text {open }}$ :omega-Ihbond ratio may explain the poor performance of equilibrium REMD-V.

How do the conformational equilibria of URP and UII differ? Both exhibit predominantly open conformations in aqueous solution but UII shows a higher population of folded conformations (UII: 28\%, URP: 14\%). This result is consistent with the possible interdependence of ring and tail conformation in UII but not URP, and supports the hypothesis that the N-terminal tail facilitates the formation of folded ring conformations.

\section{Conclusions}

Conformation and dynamics of UII and URP in aqueous solution were explored and classified by combining computational and experimental methods. The two peptides exhibit similar ring conformations. The structures of both UII and URP in aqueous solution cannot be described by single conformations. As found previously for $\operatorname{Arg}^{8}$-vasopressin, ${ }^{61}$ UII and URP exist in solution in a conformational equilibrium between open and folded (saddle-like) ring conformations and in combination with extended and folded tail conformations. In contrast to vasopressin, however, the ring and tail conformations of UII are not independent of each other, so that UII behaves differently to URP, as URP lacks the tail region. Folded (saddle-like) conformations of URP appear only 
transiently in unrestricted MD simulations and the equilibrium distribution of conformations that results from REMD simulations and agrees best with experimental ${ }^{1} \mathrm{H}$ chemical shifts is $86 \%$ open : $14 \%$ folded. The corresponding equilibrium for UII is $72 \%$ open $: 28 \%$ folded. These data suggest that the free-energy penalty for a possible folded biologically active conformation is approximately $1.1 \mathrm{kcal} \mathrm{mol}^{-1}$ for URP but considerably smaller (approximately $0.6 \mathrm{kcal} \mathrm{mol}^{-1}$ ) for UII, probably because of ring-tail interactions in UII. This difference may be significant in determining different effects of the two peptides on binding to the UII-receptor (UT2SR, UTR). The high similarity of ring conformations of UII and URP support Brancaccio's finding ${ }^{31}$ that differences in the biological function are not related to differences in ring conformations. UII and URP show the same conformational main types as the structurally related GPCR-ligand $\operatorname{Arg}^{8}$ vasopressin. However, both prefer open-type conformations in solution, in strong contrast to AVP (70\% folded conformations).

All thermodynamically accessible representative conformations of UII and URP can serve as templates for 3D ligand-based drug design or docking, the structural data are given in the SI.

The NMR data reported here supplement and complete published data. They include an almost complete assignment of the spectra of the $c i s-$ Pro $^{3}$ isomers of UII. We have developed a novel and robust procedure to extract conformational equilibria from NMR data by combining experiment with enhanced sampling simulations. The protocol was developed on $\mathrm{AVP}^{61}$ and tested here on UII and URP. It seems a powerful tool for exploring the conformational equilibria of intrinsically flexible peptides. In the case of UII and URP, we have used REMD to determine the calculated equilibrium concentrations, rather than the metadynamics procedure used for AVP. Future work will evaluate a variety of enhanced-sampling protocols in order to determine the most suitable for peptide conformational equilibria. 
The protocol tested and published ${ }^{61}$ for $\mathrm{Arg}^{8}$-vasopressin and based on proton chemical shifts also yields well-defined predictions for UII and URP, here using REMD to determine the calculated equilibrium concentrations.

Unfortunately, we have little information about the lifetimes of the individual conformations. The conformational equilibria are fast on the NMR time scale but too slow for us to be able to sample them adequately in unbiased simulations.

\section{ASSOCIATED CONTENT}

\section{Supporting Information}

The Supporting Information is available free of charge on the ACS Publications website at DOI: 10.1021/acs.jcim.6b00706.

Details of MD simulations, conformational analysis, principal component analysis, NMR experiments, DFT calculations, REMD equilibrium models, ${ }^{13} \mathrm{C}$ linear regression, sensitivity analysis of metrics, ${ }^{15} \mathrm{~N}$ linear regression, tables of experimental and calculated ${ }^{1} \mathrm{H},{ }^{13} \mathrm{C},{ }^{15} \mathrm{~N}$ chemical shifts. (PDF)

Coordinate files of representatives. (ZIP)

\section{AUTHOR INFORMATION \\ Corresponding Author \\ *E-mail: tim.clark@,fau.de}

\section{Notes}

The authors declare no competing financial interest. 


\section{ACKNOWLEDGMENTS}

This work was supported by the European project "Peptide Research Network of Excellence" PeReNE as part of the Interreg IVA France (Channel) - England 20072014 program (Interreg EU). NM, MM, and JWE are grateful to AstraZeneca for their support. We thank Helene Castel and Jérôme Leprince (University of Rouen, France) for helpful discussions. Isabelle Milazzo (University of Rouen, France) is acknowledged for providing NMR-structures of hUII and URP for the CHARMM simulations. 


\section{REFERENCES}

1. Bern, H. A.; Lederis, K., A Reference Preparation for the Study of Active Substances in the Caudal Neurosecretory System of Teleosts. J. Endocrin. 1969, 45, Suppl:xi-xii.

2. Ames, R. S.; Sarau, H. M.; Chambers, J. K.; Willette, R. N.; Aiyar, N. V.; Romanic, A. M.; Louden, C. S.; Foley, J. J.; Sauermelch, C. F.; Coatney, R. W.; Ao, Z.; Disa, J.; Holmes, S. D.; Stadel, J. M.; Martin, J. D.; Liu, W. S.; Glover, G. I.; Wilson, S.; McNulty, D. E.; Ellis, C. E.; Elshourbagy, N. A.; Shabon, U.; Trill, J. J.; Hay, D. W.; Ohlstein, E. H.; Bergsma, D. J.; Douglas, S. A., Human Urotensin-II is a Potent Vasoconstrictor and Agonist for the Orphan Receptor GPR14. Nature 1999, 401, 282-286.

3. Marchese, A.; Heiber, M.; Nguyen, T.; Heng, H. H.; Saldivia, V. R.; Cheng, R.; Murphy, P. M.; Tsui, L. C.; Shi, X.; Gregor, P.; et al., Cloning and Chromosomal Mapping of Three Novel Genes, GPR9, GPR10, and GPR14, Encoding Receptors Related to Interleukin 8, Neuropeptide Y, and Somatostatin Receptors. Genomics 1995, 29, 335-344.

4. Mori, M.; Sugo, T.; Abe, M.; Shimomura, Y.; Kurihara, M.; Kitada, C.; Kikuchi, K.; Shintani, Y.; Kurokawa, T.; Onda, H.; Nishimura, O.; Fujino, M., Urotensin II is the endogenous ligand of a G-protein-coupled orphan receptor, SENR (GPR14). Biochem. Biophys. Res. Commun. 1999, 265, 123-129.

5. Nothacker, H. P.; Wang, Z.; McNeill, A. M.; Saito, Y.; Merten, S.; O'Dowd, B.; Duckles, S. P.; Civelli, O., Identification of the Natural Ligand of an Orphan G-Protein-Coupled Receptor Involved in the Regulation of Vasoconstriction. Nat. Cell Biol. 1999, 1, 383-385.

6. Liu, Q.; Pong, S. S.; Zeng, Z.; Zhang, Q.; Howard, A. D.; Williams, D. L., Jr.; Davidoff, M.; Wang, R.; Austin, C. P.; McDonald, T. P.; Bai, C.; George, S. R.; Evans, J. F.; Caskey, C. T., Identification of Urotensin II as the Endogenous Ligand for the Orphan G-Protein-Coupled Receptor GPR14. Biochem. Biophys. Res. Commun. 1999, 266, 174-178.

7. Vaudry, H.; Do Rego, J. C.; Le Mevel, J. C.; Chatenet, D.; Tostivint, H.; Fournier, A.; Tonon, M. C.; Pelletier, G.; Conlon, J. M.; Leprince, J., Urotensin II, From Fish to Human. Ann. N. Y. Acad. Sci. 2010, 1200, 53-66.

8. Vaudry, H.; Leprince, J.; Chatenet, D.; Fournier, A.; Lambert, D. G.; Le Mevel, J. C.; Ohlstein, E. H.; Schwertani, A.; Tostivint, H.; Vaudry, D., International Union of Basic and Clinical Pharmacology. XCII. Urotensin II, Urotensin II-Related Peptide, and their Receptor: From Structure to Function. Pharmacol. Rev. 2015, 67, 214-258.

9. Tostivint, H.; Quan, F. B.; Bougerol, M.; Kenigfest, N. B.; Lihrmann, I., Impact of Gene/Genome Duplications on the Evolution of the Urotensin II and Somatostatin Families. Gen. Comp. Endocrinol. 2013, 188, 110-117.

10. Merlino, F.; Di Maro, S.; Munaim Yousif, A.; Caraglia, M.; Grieco, P., Urotensin-II Ligands: An Overview from Peptide to Nonpeptide Structures. J. Amino Acids 2013, 2013, 979016.

11. Tostivint, H.; Ocampo Daza, D.; Bergqvist, C. A.; Quan, F. B.; Bougerol, M.; Lihrmann, I.; Larhammar, D., Molecular Evolution of GPCRs: Somatostatin/Urotensin II Receptors. J. Mol. Endocrinol. 2014, 52, T61-86.

12. Sugo, T.; Murakami, Y.; Shimomura, Y.; Harada, M.; Abe, M.; Ishibashi, Y.; Kitada, C.; Miyajima, N.; Suzuki, N.; Mori, M.; Fujino, M., Identification of Urotensin II-Related Peptide as the Urotensin II-Immunoreactive Molecule in the Rat Brain. Biochem. Biophys. Res. Commun. 2003, 310, 860-868. 
13. Chatenet, D.; Nguyen, T. T.; Letourneau, M.; Fournier, A., Update on the Urotensinergic System: New Trends in Receptor Localization, Activation, and Drug Design. Front. Endocrinol. 2012, 3-3.

14. Zhu, Y. C.; Zhu, Y. Z.; Moore, P. K., The Role of Urotensin II in Cardiovascular and Renal Physiology and Diseases. Br. J. Pharmacol. 2006, 148, 884-901.

15. Chatenet, D.; Dubessy, C.; Leprince, J.; Boularan, C.; Carlier, L.; Ségalas-Milazzo, I.; Guilhaudis, L.; Oulyadi, H.; Davoust, D.; Scalbert, E.; Pfeiffer, B.; Renard, P.; Tonon, M.-C.; Lihrmann, I.; Pacaud, P.; Vaudry, H., Structure-Activity Relationships and Structural Conformation of a Novel Urotensin II-Related Peptide. Peptides 2004, 25, 1819-1830.

16. Labarrere, P.; Chatenet, D.; Leprince, J.; Marionneau, C.; Loirand, G.; Tonon, M. C.; Dubessy, C.; Scalbert, E.; Pfeiffer, B.; Renard, P.; Calas, B.; Pacaud, P.; Vaudry, H., StructureActivity Relationships of Human Urotensin II and Related Analogues on Rat Aortic Ring Contraction. J. Enzyme Inhib. Med. Chem. 2003, 18, 77-88.

17. Bucharles, C.; Bizet, P.; Arthaud, S.; Arabo, A.; Leprince, J.; Lefranc, B.; Cartier, D.; Anouar, Y.; Lihrmann, I., Concordant Localization of Functional Urotensin II and Urotensin IIRelated Peptide Binding Sites in the Rat Brain: Atypical Occurrence Close to the Fourth Ventricle. J. Comp. Neurol. 2014, 522, 2634-2649.

18. Douglas, S. A.; Naselsky, D.; Ao, Z.; Disa, J.; Herold, C. L.; Lynch, F.; Aiyar, N. V., Identification and Pharmacological Characterization of Native, Functional Human Urotensin-II Receptors in Rhabdomyosarcoma Cell Lines. Br. J. Pharmacol. 2004, 142, 921-932.

19. Jarry, M.; Diallo, M.; Lecointre, C.; Desrues, L.; Tokay, T.; Chatenet, D.; Leprince, J.; Rossi, O.; Vaudry, H.; Tonon, M. C.; Prezeau, L.; Castel, H.; Gandolfo, P., The Vasoactive Peptides Urotensin II and Urotensin II-Related Peptide Regulate Astrocyte Activity Through Common and Distinct Mechanisms: Involvement in Cell Proliferation. Biochem. J. 2010, 428, 113-124.

20. Ashton, N., Renal and Vascular Actions of Urotensin II. Kidney Int. 2006, 70, 624-629.

21. Stirrat, A.; Gallagher, M.; Douglas, S. A.; Ohlstein, E. H.; Berry, C.; Kirk, A.; Richardson, M.; MacLean, M. R., Potent Vasodilator Responses to Human Urotensin-II in Human Pulmonary and Abdominal Resistance Arteries. Am. J. Physiol. Heart Circ. Physiol. 2001, 280, H925-928.

22. Chatenet, D.; Letourneau, M.; Nguyen, Q.; Doan, N.; Dupuis, J.; Fournier, A., Discovery of New Antagonists Aimed at Discriminating UII and URP-mediated Biological Activities: Insight into UII and URP Receptor Activation. Br. J. Pharmacol. 2013, 168, 807-821.

23. Kinney, W. A.; Almond Jr, H. R.; Qi, J.; Smith, C. E.; Santulli, R. J.; de Garavilla, L.; Andrade-Gordon, P.; Cho, D. S.; Everson, A. M.; Feinstein, M. A.; Leung, P. A.; Maryanoff, B. E., Structure-Function Analysis of Urotensin II and its Use in the Construction of a LigandReceptor Working Model. Angew. Chem,. Int. Ed. 2002, 41, 2940-2940.

24. Flohr, S.; Kurz, M.; Kostenis, E.; Brkovich, A.; Fournier, A.; Klabunde, T., Identification of Nonpeptidic Urotensin II Receptor Antagonists by Virtual Screening Based on a Pharmacophore Model Derived from Structure-Activity Relationships and Nuclear Magnetic Resonance Studies on Urotensin II. J. Med. Chem. 2002, 45, 1799-1805.

25. Foister, S.; Taylor, L. L.; Feng, J. J.; Chen, W. L.; Lin, A.; Cheng, F. C.; Smith, A. B., 3rd; Hirschmann, R., Design and Synthesis of Potent Cystine-Free Cyclic Hexapeptide Agonists at the Human Urotensin Receptor. Org. Lett. 2006, 8, 1799-1802.

26. McMaster, D.; Kobayashi, Y.; Rivier, J.; Lederis, K., Characterization of the Biologically and Antigenically Important Regions of Urotensin II. Proc. West. Pharmacol. Soc. 1986, 29, $205-$ 208. 
27. Bandholtz, S.; Erdmann, S.; von Hacht, J. L.; Exner, S.; Krause, G.; Kleinau, G.; Grötzinger, C., Urolinin: The First Linear Peptidic Urotensin-II Receptor Agonist. J. Med. Chem. 2016, 59, 10100-10112.

28. Carotenuto, A.; Grieco, P.; Campiglia, P.; Novellino, E.; Rovero, P., Unraveling the Active Conformation of Urotensin II. J. Med. Chem. 2004, 47, 1652-1661.

29. Grieco, P.; Carotenuto, A.; Patacchini, R.; Maggi, C. A.; Novellino, E.; Rovero, P., Design, Synthesis, Conformational Analysis, and Biological Studies of Urotensin-II Lactam Analogues. Bioorg. Med. Chem. 2002, 10, 3731-3739.

30. Lescot, E.; Sopkova-de Oliveira Santos, J.; Dubessy, C.; Oulyadi, H.; Lesnard, A.; Vaudry, H.; Bureau, R.; Rault, S., Definition of New Pharmacophores for Nonpeptide Antagonists of Human Urotensin-II. Comparison with the 3D-Structure of Human Urotensin-II and URP. $J$. Chem. Inf. Model. 2007, 47, 602-612.

31. Brancaccio, D.; Merlino, F.; Limatola, A.; Yousif, A. M.; Gomez-Monterrey, I.; Campiglia, P.; Novellino, E.; Grieco, P.; Carotenuto, A., An Investigation into the Origin of the Biased Agonism Associated with the Urotensin II Receptor Activation. J. Pept. Sci. 2015, 21, 392399.

32. Case, D. A.; Cheatham, T. E.; Darden, T.; Gohlke, H.; Luo, R.; Merz, K. M.; Onufriev, A.; Simmerling, C.; Wang, B.; Woods, R. J., The Amber Biomolecular Simulation Programs. J. Comput. Chem. 2005, 26, 1668-1688.

33. Case, D. A.; Darden, T. A.; Cheatham II, T. E.; Simmerling, C. L.; Wang, J.; Duke, R. E.; R. Luo; Crowley, M.; C.Walker, R.; Zhang, W.; Merz, K. M.; B.Wang; S. Hayik; Roitberg, A.; G. Seabra; Kolossváry, I.; F.Wong, K.; Paesani, F.; Vanicek, J.; Wu, X.; Brozell, S. R.; Steinbrecher, T.; Gohlke, H.; Yang, L.; Tan, C.; Mongan, J.; Hornak, V.; Cui, G.; Mathews, D. H.; Seetin, M. G.; Sagui, C.; V. Babin; Kollman, P. A. AMBER 10, 2008.

34. Case, D. A.; Babin, V.; Berryman, J. T.; Betz, R. M.; Cai, Q.; Cerutti, D. S.; Cheatham, T. E. I.; Darden, T. A.; Duke, R. E.; Gohlke, H.; Goetz, A. W.; Gusarov, S.; Homeyer, N.; Janowski, P.; Kaus, J.; Kolossváry, I.; Kovalenko, A.; Lee, T. S.; LeGrand, S.; Luchko, T.; Luo, R.; Madej, B. D.; Merz, K. M.; Paesani, F.; Roe, D. R.; Roitberg, A.; Sagui, C.; Salomon-Ferrer, R.; Seabra, G. M.; Simmerling, C. L.; Smith, W. S.; Swails, J.; Walker, R. C.; Wang, J.; Wolf, R. M.; Wu, X.; Kollman, P. A. AMBER 14, 2014.

35. Salomon-Ferrer, R.; Götz, A. W.; Poole, D.; Le Grand, S.; Walker, R. C., Routine Microsecond Molecular Dynamics Simulations with AMBER on GPUs. 2. Explicit Solvent Particle Mesh Ewald. J. Chem. Theor. Comput. 2013, 9, 3878-3888.

36. Goetz, A. W.; Williamson, M. J.; Xu, D.; Poole, D.; Le Grand, S.; Walker, R. C., Routine Microsecond Molecular Dynamics Simulations with AMBER on GPUs. 1. Generalized Born. $J$. Chem. Theory Comput. 2012, 8, 1542-1555.

37. Le Grand, S.; Goetz, A. W.; Walker, C. R., SPFP: Speed without Compromise - A Mixed Precision Model for GPU Accelerated Molecular Dynamics Simulations. Comput. Phys. Commun. 2013, 184, 374-380.

38. Brooks, B. R.; Brooks, C. L., 3rd; Mackerell, A. D., Jr.; Nilsson, L.; Petrella, R. J.; Roux, B.; Won, Y.; Archontis, G.; Bartels, C.; Boresch, S.; Caflisch, A.; Caves, L.; Cui, Q.; Dinner, A. R.; Feig, M.; Fischer, S.; Gao, J.; Hodoscek, M.; Im, W.; Kuczera, K.; Lazaridis, T.; Ma, J.; Ovchinnikov, V.; Paci, E.; Pastor, R. W.; Post, C. B.; Pu, J. Z.; Schaefer, M.; Tidor, B.; Venable, R. M.; Woodcock, H. L.; Wu, X.; Yang, W.; York, D. M.; Karplus, M., CHARMM: The Biomolecular Simulation Program. J. Comput. Chem. 2009, 30, 1545-614. 
39. Hornak, V.; Abel, R.; Okur, A.; Strockbine, B.; Roitberg, A.; Simmerling, C., Comparison of Multiple Amber Force Fields and Development of Improved Protein Backbone Parameters. Proteins: Struct. Funct. Genet. 2006, 65, 712-725.

40. Salt, D. W.; Hudson, B. D.; Banting, L.; Ellis, M. J.; Ford, M. G., DASH: A Novel Analysis Method for Molecular Dynamics Simulation Data. Analysis of Ligands of PPAR-Gamma. J. Med. Chem. 2005, 48, 3214-3220.

41. DASH 1.0.-2.11. www.port.ac.uk/research/cmd/software (accessed Sep, 2014 - March, 2016)

42. Case, D. A.; Darden, T. A.; Cheatham II, T. E.; Simmerling, C. L.; Wang, J.; Duke, R. E.; R. Luo; Crowley, M.; C.Walker, R.; Zhang, W.; Merz, K. M.; B.Wang; S. Hayik; Roitberg, A.; G. Seabra; Kolossváry, I.; F.Wong, K.; Paesani, F.; Vanicek, J.; Wu, X.; Brozell, S. R.; Steinbrecher, T.; Gohlke, H.; Yang, L.; Tan, C.; Mongan, J.; Hornak, V.; Cui, G.; Mathews, D. H.; Seetin, M. G.; Sagui, C.; V. Babin; Kollman, P. A. AmberTools 1.0, AmberTools 1.0; 2008.

43. Kaiser, H. F., The Application of Electronic Computers to Factor Analysis. Educ. Psychol. Meas. 1960, 20, 141-151.

44. SAR-Caddle. http://www.cepos-server.com/demoReg/SARcaddle/ (accessed Jan, 2014 Dec, 2015)

45. Bax, A.; Davis, D. G., Mlev-17-Based Two-Dimensional Homonuclear Magnetization Transfer Spectroscopy. J. Magn. Reson. 1985, 65, 355-360.

46. Kumar, A.; Ernst, R. R.; Wuthrich, K., A Two-Dimensional Nuclear Overhauser Enhancement (2D Noe) Experiment for the Elucidation of Complete Proton-Proton CrossRelaxation Networks in Biological Macromolecules. Biochem. Biophys. Res. Commun. 1980, 95, $1-6$.

47. Palmer, A. G.; Cavanagh, J.; Wright, P. E.; Rance, M., Sensitivity Improvement in ProtonDetected 2-Dimensional Heteronuclear Correlation NMR-Spectroscopy. J. Magn. Reson. 1991, 93, 151-170.

48. Kay, L. E.; Keifer, P.; Saarinen, T., Pure Absorption Gradient Enhanced Heteronuclear Single Quantum Correlation Spectroscopy with Improved Sensitivity. J. Am. Chem. Soc. 1992, 114, 10663-10665.

49. Kontaxis, G.; Stonehouse, J.; Laue, E. D.; Keeler, J., The Sensitivity of Experiments Which Use Gradient Pulses for Coherence-Pathway Selection. J. Magn. Reson. 1994, 111, 70-76.

50. Becke, A. D., Density-Functional Thermochemistry .III. The Role of Exact Exchange. $J$. Chem. Phys. 1993, 98, 5648-5652.

51. Lee, C. T.; Yang, W. T.; Parr, R. G., Development of the Colle-Salvetti Correlation-Energy Formula into a Functional of the Electron-Density. Phys. Rev. B 1988, 37, 785-789.

52. Vosko, S. H.; Wilk, L.; Nusair, M., Accurate Spin-Dependent Electron Liquid Correlation Energies for Local Spin-Density Calculations - A Critical Analysis. Can. J. Phys. 1980, 58, 12001211.

53. Stephens, P. J.; Devlin, F. J.; Chabalowski, C. F.; Frisch, M. J., Ab-Initio Calculation of Vibrational Absorption and Circular-Dichroism Spectra Using Density-Functional Force-Fields. J. Phys. Chem. 1994, 98, 11623-11627.

54. Ditchfield, R.; Hehre, W. J.; Pople, J. A., Self-Consistent Molecular-Orbital Methods .IX. Extended Gaussian-Type Basis for Molecular-Orbital Studies of Organic Molecules. J. Chem. Phys. 1971, 54, 724-728. 
55. Hehre, W. J.; Ditchfield, R.; Pople, J. A. Self-Consistent Molecular-Orbital Methods .XII. Further Extensions of Gaussian-Type Basis Sets for Use in Molecular-Orbital Studies of OrganicMolecules. J. Chem. Phys. 1972, 56, 2257-2261.

56. Hariharan P. C.; Pople, J. A., The Influence of Polarization Functions on Molecular-Orbital Hydrogenation Energies. Theor. Chim. Acta 1973, 28, 213-222.

57. Hariharan P. C.; Pople, J. A., Accuracy of AH Equilibrium Geometries by Single Determinant Molecular-Orbital Theory. Mol. Phys. 1974, 27, 209-214.

58. Gordon, M. S.; Binkley, J. S.; Pople, J. A.; Pietro, W. J.; Hehre, W. J., Self-Consistent Molecular-Orbital Methods. 22. Small Split-Valence Basis Sets for Second-Row Elements. J. Am. Chem. Soc. 1982, 104, 2797-2803.

59. Frisch, M. J.; Trucks, G. W.; Schlegel, H. B.; Scuseria, G. E.; Robb, M. A.; Cheeseman, J. R.; Scalmani, G.; Barone, V.; Mennucci, B.; Petersson, M.; Nakatsuji, H.; Caricato, M.; Li, X.; Hratchian, H. P.; Izmaylov, A. F.; Bloino, J.; Zheng, G.; Sonnenberg, J. L.; Hada, M.; Ehara, M.; Toyota, K.; Fukuda, R.; Hasegawa, J.; Ishida, M.; Nakajima, T.; Honda, Y.; Kitao, O.; Nakai, H.; Vreven, T.; Montgomery, J. A. J.; Peralta, J. E.; Ogliaro, F.; Bearpark, M.; Heyd, J. J.; Brothers, E.; Kudin, K. N.; Staroverov, V. N.; Keith, T. A.; Kobayashi, R.; Normand, J.; Raghavachari, K.; Rendell, A.; Burant, J. C.; Iyengar, S. S.; Tomasi, J.; Cossi, M.; Rega, N.; Millam, J. M.; Klene, M.; Knox, J. E.; Cross, J. B.; Bakken, V.; Adamo, C.; Jaramillo, J.; Gomperts, R.; Stratmann, R. E.; Yazyev, O.; Austin, A. J.; Cammi, R.; Pomelli, C.; Ochterski, J. W.; Martin, R. L.; Morokuma, K.; Zakrzewski, V. G.; Voth, G. A.; Salvador, P.; Dannenberg, J. J.; Dapprich, S.; Daniels, A. D.; Farkas, O.; Foresman, J. B.; Ortiz, J. V.; Cioslowski, J.; Fox, D. J. Gaussian 09, Revision C.01, Revision C.01; Gaussian, Inc.: Wallingford CT, 2010.

60. Tomasi, J.; Mennucci, B.; Cammi, R., Quantum Mechanical Continuum Solvation Models. Chem. Rev. 2005, 105, 2999-3093.

61. Haensele, E.; Saleh, N.; Read, C. M.; Banting, L.; Whitley, D. C.; Clark, T., Can Simulations and Modeling Decipher NMR Data for Conformational Equilibria? ArginineVasopressin. J. Chem. Inf. Model. 2016, 56, 1798-1807.

62. Haensele, E.; Banting, L.; Whitley, D. C.; Clark, T., Conformation and Dynamics of 8Arg-Vasopressin in Solution. J. Mol. Model. 2014, 20, 2485(17).

63. Sikorska, E.; Rodziewicz-Motowidlo, S., Conformational Studies of Vasopressin and Mesotocin Using NMR Spectroscopy and Molecular Modelling Methods. Part I: Studies in Water. J. Pept. Sci. 2008, 14, 76-84.

64. Cavanagh, J.; Fairbrother, W. J.; Palmer III, A. G.; Rance, M.; Skelton, N. J., Protein NMR Spectroscopy: Principles and Practice. 2nd ed.; Elsevier Ltd.: Oxford, 2006; 996.

65. Grathwohl, C.; Wüthrich, K., NMR Studies of the Rates of Proline Cis-Trans Isomerization in Oligopeptides. Biopolymers 1981, 20, 2623-2633.

66. Vitagliano, L.; Berisio, R.; Mastrangelo, A.; Mazzarella, L.; Zagari, A., Preferred Proline Puckerings in Cis and Trans Peptide Groups: Implications for Collagen Stability. Protein Sci. 2001, 10, 2627-2632.

67. Smith, S. G.; Goodman, J. M., Assigning Stereochemistry to Single Diastereoisomers by GIAO NMR Calculation: The DP4 Probability. J. Am. Chem. Soc. 2010, 132, 12946-12959. 
Table of Contents Graphic

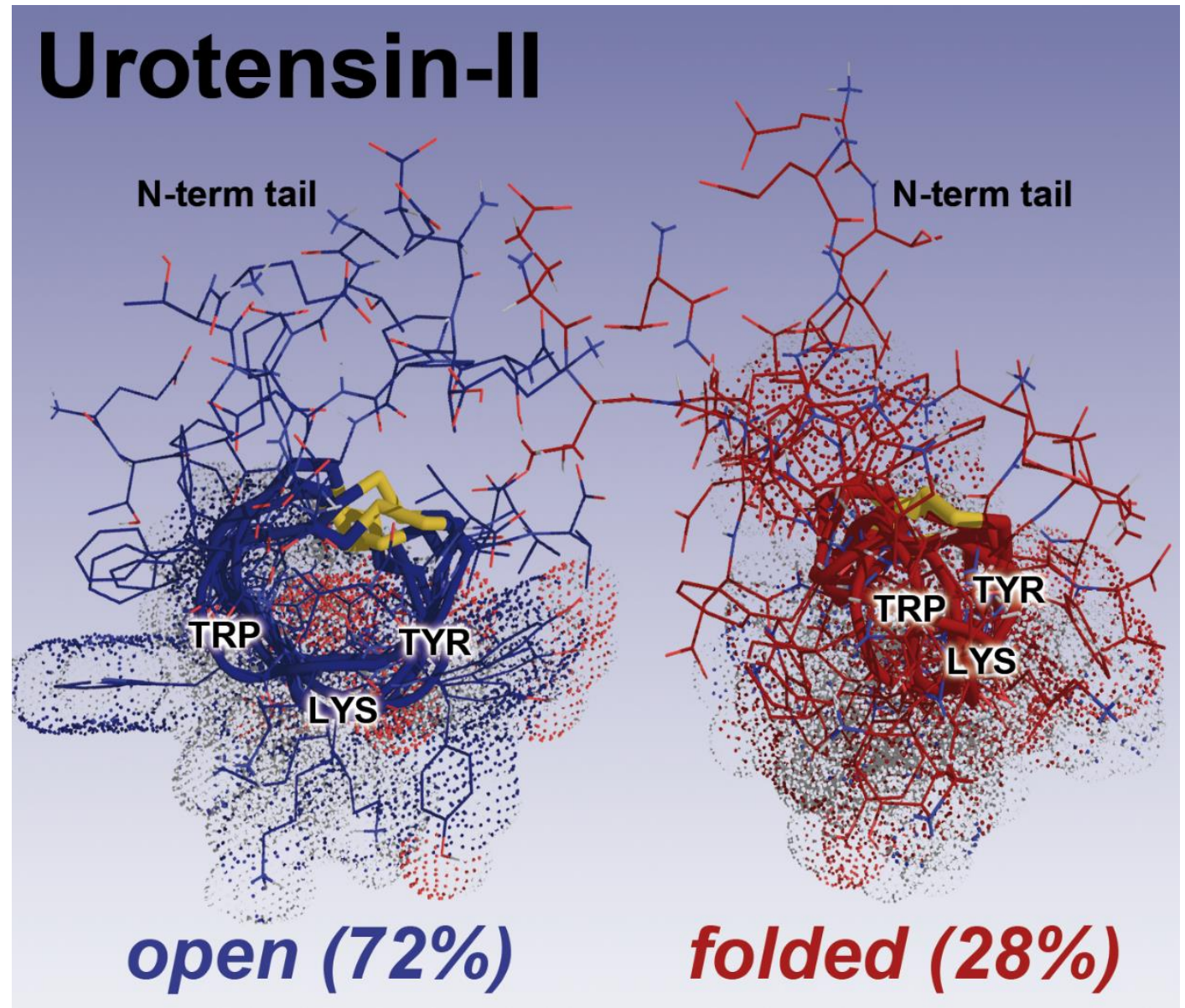

